\title{
Ritual Economy and the Organization of Scioto Hopewell Craft Production: Insights from the Outskirts of the Mound City Group
}

\author{
Timothy D. Everhart (D) and Bret J. Ruby
}

\begin{abstract}
This article offers insights into the organization of Scioto Hopewell craft production and examines the implications of this organization through the lens of ritual economy. We present a novel analysis of investigations at the North 40 site, concluding that it is a craft production site located on the outskirts of the renowned Mound City Group. High-resolution landscape-scale magnetic survey revealed a cluster of three large structures and two rows of associated pits; one of the buildings and three of the pits were sampled in excavations. Evidence from the North 40 site marks this as the best-documented Scioto Hopewell craft production site. Mica, chert, and copper were crafted here in contexts organized outside the realm of domestic household production and consumption. Other material remains from the site suggest that crafting was specialized and embedded in ceremonial contexts. This analysis of the complex organization of Scioto Hopewell craft production provides grounds for further understanding the elaborate ceremonialism practiced by Middle Woodland (AD 1-400) societies and adds to the known complexity of craft production in small-scale societies. Furthermore, this article contributes to a growing body of literature demonstrating the utility of ritual economy as a framework for approaching the sociality of small-scale societies.
\end{abstract}

Keywords: ritual economy, craft production, small-scale societies, Scioto Hopewell, Middle Woodland

Este articulo proporciona nuevas perspectivas sobre la organización de la producción artesanal Scioto Hopewell y también examina las implicaciones de la organización artesanal aplicando la economía ritual como marco. Presentamos un análisis distinto sobre las investigaciones en el sitio Norte 40 y concluimos que es un sitio dedicado a la producción artesanal en las afueras de el renombrado Mound City Group. Prospecciones magnéticas de alta resolución a escala grande han revelado una agrupación de tres estructuras grandes y dos filas de pozos asociados con estas estructuras. Los materiales que provienen de excavaciones en una de estas estructuras y tres de estos pozos nos indican que el sitio Norte 40 es uno de los mejores ejemplos de la producción artesanal Scioto Hopewell. Productos hechos con mica, sílex, y cobre fueron producidos en contextos organizados aparte de la producción y consumo domestico. Otros materiales que provienen de este sitio también revelan que la producción artesanal era especializada y estaba entrelazada con contextos ceremoniales. Este análisis, el cual se enfoca en la organización compleja de la producción artesanal Scioto Hopewell, nos proporciona la base para obtener un entendimiento mas complejo sobre ceremonias elaboradas de sociedades Middle Woodland (1-400 dC). También nos enseña que la organización de la producción artesanal de sociedades de pequeña escala resulta ser mas compleja de lo que previamente teníamos entendido. Es mas, este articulo contribuye a creciente evidencias que nos demuestran la utilidad de la economía ritual como un marco para interpretar las dinámicas entre las sociedades de pequeña escala.

Palabras clave: economía ritual, producción artesanal, sociedades de pequeña escala, Scioto Hopewell, Middle Woodland

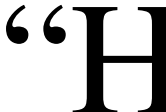

opewell" is an expansive cultural phenomenon that engaged

from the Great Plains to the Chesapeake Bay, small-scale societies scattered from the Canadian Shield to the Gulf Coast, during the Middle Woodland period (ca. AD

Timothy D. Everhart $\square$ University of Michigan, Department of Anthropology and Museum of Anthropological Archaeology, 610 East University Avenue, Ann Arbor, MI 48109, USA (timever@umich.edu, corresponding author) https://orcid.org/ 0000-0002-2886-1799

Bret J. Ruby $\square$ National Park Service, Hopewell Culture National Historical Park, 16062 State Route 104, Chillicothe, OH 45601, USA

American Antiquity 85(2), 2020, pp. 279-304

Copyright (C) 2020 by the Society for American Archaeology. This is an Open Access article, distributed under the terms of the Creative Commons Attribution licence (http://creativecommons.org/licenses/by/4.0/), which permits unrestricted re-use, distribution, and reproduction in any medium, provided the original work is properly cited.

doi:10.1017/aaq.2019.105 
1-400). Traditionally, archaeologists identify Hopewellian engagement by the presence of a small suite of highly distinctive artistic crafts including bicymbal copper earspools, metaljacketed panpipes, platform effigy pipes, and diagnostic styles of lithic tools and ceramics (Griffin 1952, 1967; Seeman 2004). Middle Woodland societies across the Midwest, Midsouth, and Gulf Coast had variable settlementsubsistence systems and social organizations and engaged with Hopewell ceremonialism at different times and in different ways (see Abrams 2009; Wright 2017). Hopewellian groups, most notably in Ohio, are known for the construction of massive earthen monuments-mounds of various scales and ditch-and-embankment enclosures often of geometric forms, sometimes aligned to solar and lunar standstills. Likewise, they are renowned for the diverse and ornate works of art that were interred within these mounds (Willoughby 1916). The focus of our analysis, the Scioto Hopewell (AD 1-400), located in the central Scioto Valley $(\mathrm{CSV})^{1}$ of southern Ohio (Greber 1991), were foragerfarmers, utilizing the suite of cultigens and domesticates known as the Eastern Agricultural Complex (EAC; Carr 2008a:79-90; Wymer 1992, 1996, 1997), living in sedentary hamlets on floodplains (Dancey and Pacheco 1997; Ruby et al. 2005), organized in nonhierarchical communities (Byers 2004, 2011; Case and Carr 2008; Coon 2009; Greber 1979).

Hopewellian material symbols-including mica cutouts, miniature and hypertrophic copper celts, obsidian spearpoints, sheet copper headdresses, carved bone whistles, and so on-were of various media, and although sometimes composed of long-utilized materials or occasionally employing preexisting styles, they were of unprecedented diversity, technical skill, and quantity. Many of these media were exotic raw materials-pipestone, obsidian, silver, copper, galena, mica, Knife River chert, marine shellacquired over the greater part of eastern North America. These materials gained importance not only by virtue of the distance traveled for their acquisition but referentially, as "metaphorical connections to the earth, sky, and directionality" (Seeman 2004:62). Hopewellian art is thematically dominated by animal motifs, also incorporating ancestral and other symbolism, that were employed in a media-specific fashion with no pervasive style (Seeman 2004:64).

Scioto Hopewell peoples used these highly crafted arts in a complex ceremonialism. Hopewellian art was utilized in performance, as evinced by sculptural examples of people dressed in zoomorphic shamanic costumes (Carr 2008b:180-199; Cowan 1996:134; Giles 2019; Seeman 2004:61; see also Dragoo and Wray 1964) and human burials arrayed in elaborate regalia (e.g., DeBoer 2004). Similarly, art may have functioned in tableaux narrating ritual dramas (Carr and Novotny 2015). Art also served as gifts among human and other-than-human beings (Carr 2008b:255-262; Seeman 2004: 62-65). Hopewellian art had "social lives" (Penney 2004:50) or personhood (Seeman et al. 2019:1095), often being intentionally burned, broken, or "killed" before being interred and eventually mounded over.

The prominence of the communal construction of ritual landscapes (Bernardini 2004) and prevalence of material symbols (Seeman 2004:59; cf. Spielmann 2009:179) in Scioto Hopewell society make the lens of ritual economy especially apropos. This framework allows us to explore the relationships of these elements of Scioto Hopewell ceremonialism to subsistence, settlement, and social organization (Miller 2015:136). Here we focus specifically on the role of craft production, defined as "the manufacture of items unrelated to, or at a level of intensity beyond, the subsistence needs of the 'average' household" (Pluckhahn et al. 2018:115). Crafting, at the scale documented, had the potential to reorganize the subsistence economy and to restructure social relations. Yet the organization of craft production is poorly documented and understood (Wright and Loveland 2015:149). Here we argue that the North 40 site (33RO338), situated just outside the Mound City Group (33RO32) earthwork complex, is the best-documented Scioto Hopewell craft production site. We analyze the organization of Scioto Hopewell craft production through the framework of ritual economy to demonstrate how the organization of production outside of the household or domestic contexts impacted society more broadly and 
shaped larger-scale structures in Scioto Hopewell society.

\section{Ritual Economy and Craft Production in Small-Scale Societies}

Increasingly, archaeologists are using "ritual economy" as an analytical lens to approach a variety of social phenomena (e.g., Wells and Davis-Salazar, ed. 2007; Wells and McAnany 2008). Ritual economy refers to the dialectical relationship between ritual and economy: on the one hand, referencing the necessary economic considerations and consequences of engaging in particular rituals and, on the other, highlighting the influence of ritually mediated values, worldviews, and meanings on economic practices (Miller 2015:124; Wells 2006:284; Wells and Davis-Salazar 2007:3). Some scholars dichotomize these relationships heuristically as the "economics of ritual" and the "ritual of economy" (Watanabe 2007:301). Ritual economies often operate fundamentally differently in small-scale societies due to limited population densities and the lack of political centralization (Spielmann 2002, 2008). Small-scale societies are those that contain several hundred to several thousand people united by diffuse political structures organized around kin groups, wherein "ritual and belief define the rules, practices, and rationale for much of the production, allocation, and consumption" (Spielmann 2002:203). This leads some scholars to suggest that discussion of social dynamics in small-scale societies inherently involves consideration of ritual economy (Miller 2015:125; Spielmann 2009:179; Watanabe 2007:313).

Here we focus on the economics of ritual, one aspect of which is the production of crafts that are used in ritual and whose creation is also often ritualized (Miller 2015; Wright and Loveland 2015). Craft production can be organized in variable ways (Brumfiel and Earle 1987:5; Childe 1950:7-8; Costin 1991:4; Spielmann 2002:202). Archaeologically, craft production is identified by the recovery of "raw materials, debris, tools, and facilities associated with production" (Costin 1991:19). Spielmann (2002:198, 201-202) suggests that community specialization-households within a community specializing in the production of a specific craft -is the prevalent organizational strategy of craft production among small-scale societies worldwide (see also Malinowski 1935:22). Yet she (Spielmann 2002:202, 2009:183) notes a variant in some societies where ceremonial centers, rather than residential contexts, are the loci for aggregation and craft production. Here, artisans and their productive activities are carried out in corporate or communal facilities-workshops-embedded in ritual contexts, outside the domestic realm, and often associated with other religious and mortuary activities. Workshops are relatively unknown from small-scale societies, being far more common in complex societies. The restriction of craft production to ceremonial precincts may be a function of ritual practitioners exercising control over the materialization of ideology, logistical exigencies arising from dispersed patterns of residential settlement, or even the need to "deal with" the power inherent in certain raw materials and ritual paraphernalia (DeMarrais et al. 1996; Seeman et al. 2019; Spielmann 2009:183).

The production of objects and spaces in preparation for ritual is often an actively ritualized process in and of itself (Costin 1998:5; Miller 2015:137; Spielmann 2002:200; Wright and Loveland 2015). Inherent in the creation or transformation of objects imbued with power and meaning, whose production is divorced from the domestic sphere, is the fact that the practices of creation are themselves spiritually powerful. It follows, then, that the transformation of these raw materials into crafts may be restricted within a population beyond just those possessing the prerequisite skill. In fact, in small-scale societies, the warrant to produce ritual paraphernalia may be gendered or restricted to a few individuals and may require specific esoteric knowledge (Spielmann 2002:200, 2009:180). Further, in places of production set aside from the domestic sphere, the places themselves may be imbued with ideological or religious significance (Spielmann 2002:200).

\section{Scioto Hopewell Craft Production}

Craft production among Scioto Hopewell peoples was a complicated affair involving three 
essential parts: (1) the acquisition of a multitude of exotic raw materials (e.g., pipestone, obsidian, silver, copper, galena, mica, Knife River chert) from distant sources; (2) the transformation of these materials into sacred and symbolically charged objects; and (3) the varied rituals, exchanges, and performances utilizing these objects before their deliberate deposition in shrines and mortuary contexts. These parts have received uneven scholarship. Researchers (e.g., Emerson et al. 2013; Hill et al. 2018; Hughes 2006) have made much progress identifying sources of exotic materials. Their findings are important in building and interrogating models for how and with and by whom these materials were obtained (Bernardini and Carr 2005:633-635; Carr 2005a; Spielmann 2009:180). Similarly, analysis and interpretation of ritual and mortuary contexts have led to much insight into the iconography and the religious significance of these crafts (Carr and Case 2005; Carr et al. 2008; Giles 2010; Hall 1979) and the nature of the ceremonial events preceding their deposition (see Carr 2005a, 2008b). Yet our understanding of the production of these crafts has lagged behind (Wright and Loveland 2015:138-139).

Although the nature of Scioto Hopewell craft production has been explored through analyses of numerous finished products, direct evidence of crafting has been elusive. The rarity of crafting debris at domestic sites leads most researchers to conclude that craft production took place in or near Scioto Hopewell earthworks (e.g., Coon 2009:57; Spielmann 2013:149). Both copper earspools (Ruhl and Seeman 1998) and textiles (Carr and Mazlowski 1995) seem to have styles corresponding to earthwork sites, suggesting localized centers of production. Spielmann (2009:183, see also 2013:149-150), noting that some earspools are assembled of two stylistically different halves and that some earspool pairs are unmatched (Greber and Ruhl 1989; Ruhl and Seeman 1998), suggests that they were made by different craftspeople, perhaps in communal workshops. Some textiles contain different kinds of yarn, suggesting either that multiple artisans worked together or that they were at least produced in a facility with a variety of available yarn (Wimberley 2004; see also Spielmann
2009:184, 2013:150). Conversely, Penney suggests that

a relatively small group of artists created hundreds of individual pipes closely conforming in scale, technique, style, and image, even to the extent that the Mound City and Tremper sets include pipes that virtually duplicated their effigy in pose, attitude, and detail [2004:52; see also Minich 2004; Penney 1988].

To date, archaeologists have identified few compelling examples of craft production sites in the central Scioto Valley region (see Coon 2009:57; Wright and Loveland 2015:138-139). For decades, the seven wooden-post structures within the enclosure at the Seip Earthworks (33RO40) were interpreted as craft production workshops (Baby and Langlois 1979). While the associated artifact assemblages were initially thought to be the residue of activities that took place inside the structures, reanalysis identified these materials as secondary deposits included in low mounds overlying the structures (Greber 2009a). Thus, Greber (2009b:171, ed. 2009) reinterpreted these structures as places of repeated rituals over the course of generations. Similarly, the discovery of a single large pit (Feature 9) containing stacked clusters of alternating ceramic sherds and cut mica sheets at the Hopeton Earthworks (33RO26) was briefly interpreted as evidence of craft production (Lynott 2014:122-123). Yet the pit was primarily filled with utilitarian refuse, leading to the interpretation that these materials were instead the residue of a ceremonial event (Lynott 2014:123; Spielmann 2009:186-188). Finally, a season of excavation at the Datum $\mathrm{H}$ site at Hopewell Mound Group (33RO27) gathered intriguing data, including nearly 250 bladelets and a small amount of mica and obsidian (Pacheco et al. 2012). Yet no structure has been documented, and, to date, artifact analyses have yet to be completed, limiting any conclusions regarding the presence of craft production at the site.

Though little evidence of craft production has been reported in the Scioto River Valley, Miller (2014, 2015) documented craft production through a microwear analysis of bladelets at the Fort Ancient Earthworks in the Little Miami 
River Valley of southwestern Ohio. $\mathrm{He}$ (2015:135-136) documented relatively intense craft production in three areas based on bladelet use-wear and crafting in a fourth area evidenced by worked exotic materials. But the limited direct evidence-production loci and debris (Costin 1991:18-19) ${ }^{2}$-restricts insights into how craft production was organized here. Comparisons between this site and those in the CSV must be qualified given the presence of habitations (Connolly 1997; Lazazzera 2004), its differing physiographic position and corporateceremonial context (as a hilltop enclosure), and the markedly larger scale of acquisition of exotic raw materials and overall production and consumption of crafts in the CSV. A production area for lithic objects has also been located and analyzed in the Little Miami River Valley, near the Turner Earthworks (Nolan et al. 2007), as well as similar lithic production sites near the Flint Ridge quarry in east-central Ohio (Lepper et al. 2001; Mills 1921). Despite these examples, the close clustering of earthwork centers (Ruby et al. 2005:160) in the CSV suggests that the logistics of craft production could have been organized differently, with, for example, centralized crafting "schools" or sites of production serving multiple residential communities or, conversely, specialized production centers distributed across multiple residential communities.

This analysis of the materials recovered from the North 40 site demonstrates that it is now the best-documented Scioto Hopewell craft production site. The material remains represent the raw material and debris (e.g., chert debitage, mica, and copper), tools (e.g., chert and crystal quartz bladelets, bone perforators, and an obsidian unifacial tool), and facilities (structures and refuse pits) of craft production. Specifically, the patterned deposition of debris in aligned pits and the architectural scale of the sampled building (Structure 1) make clear that this was a locale of craft production. Some of the materials (e.g., ceramic vessels, EAC seeds, and a ceramic pipe) represent the residue of ritual activities intertwined with craft production. The North 40 site-following geophysical survey, smallscale excavation, and analyses of artifacts associated with three pit features and a large timberpost structure (Structure 1)-illuminates the nature and organization of craft production among Scioto Hopewell peoples.

\section{The North 40 Site}

The North 40 site is an open occupation located about 300 m north of the Mound City Group, a renowned Hopewellian mound-and-earthwork complex consisting of at least 25 mounds surrounded by an earthen embankment enclosing approximately 6.5 ha (Figure 1; Brown 2012:15, 31; Lynott and Monk 1985:3; Squier and Davis 1848). Both sites are located near the edge of a Wisconsinan-age glacial outwash terrace that drops precipitously to the active floodplain and western bank of the Scioto River about $10 \mathrm{~m}$ below. The proportion of black locust (Robinia pseudoacacia), honey locust (Gleditsia triacanthos), and other secondary growth species represented in the charcoal assemblage suggests significant human modification of this area, including clearing some portion of the oldgrowth forest (Leone 2013:5; see also Wymer 1996:44-45, 47). The North 40 site consists of at least three timber-post structures (identified through magnetic gradient surveys) and a series of related pit features (Figure 1). Structure 1 and three nearby pit features (Pits 1,2, and 3) were sampled in excavations, revealing that these pits were filled with refuse indicative of craft production and ceremonial gatherings.

The North 40 precinct hosted activity across most of the Middle Woodland period (AD 1-400). Seven samples were submitted for accelerator mass spectrometry radiocarbon dating: four samples from postholes of Structure 1 and one sample from each of the three pits (Figure 2). The range of dates reflects a persistent and protracted, if episodic, occupation. A series of pairwise $T$-tests $(\alpha=0.05)$ across the set demonstrates that there is no significant hiatus in the occupation. The summed probabilities place the occupation between cal AD 5-AD $220 \quad(68 \%$ probability), or cal $51 \mathrm{BC}-\mathrm{AD} 376$ (95\% probability; analyzed with Stuiver et al. 2019). These dates are contemporaneous with the use of Mound City (Brown 2012:45-53), and the site's occupation may well have traced the ebb and flow of ceremonial activities at Mound City. 


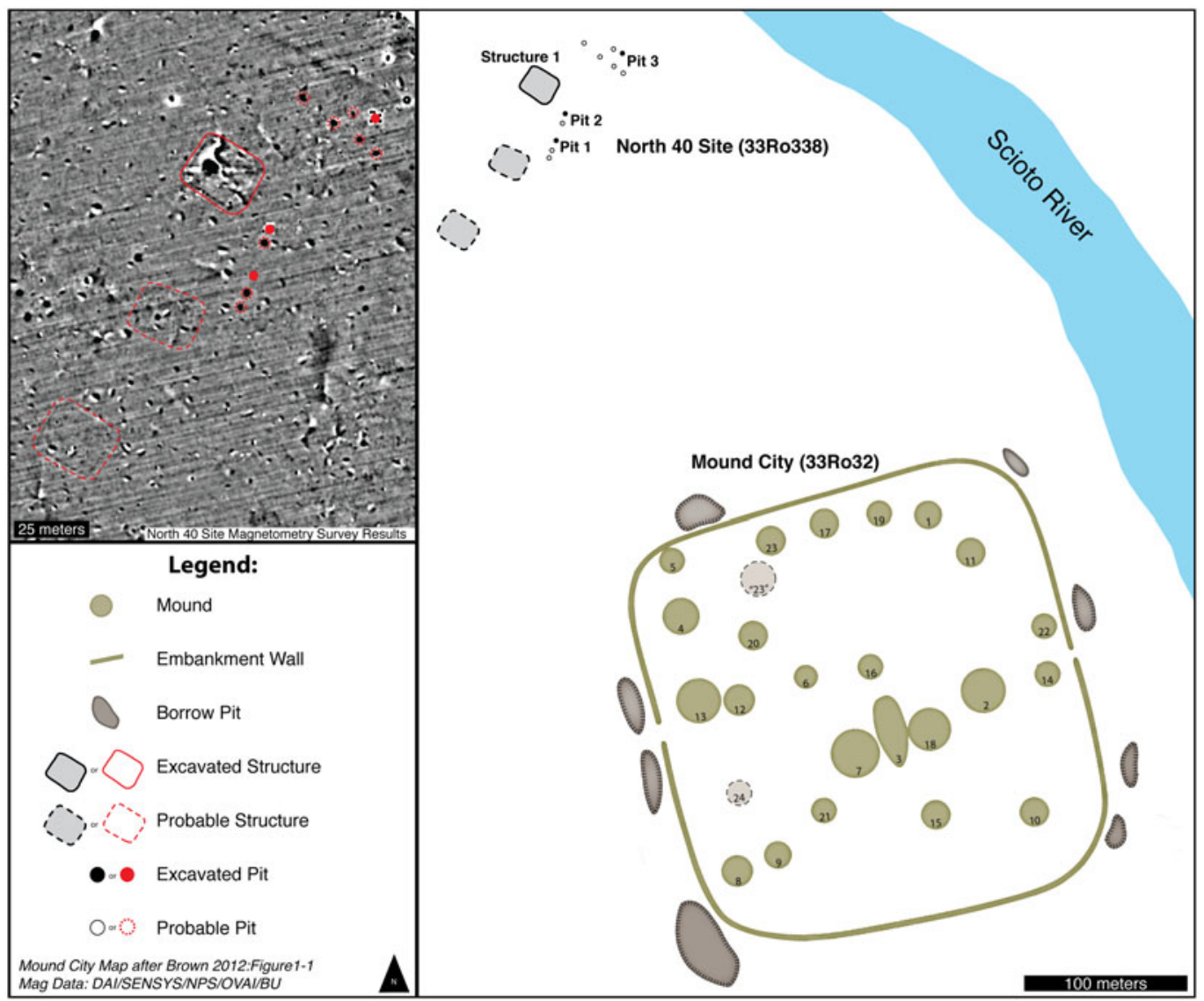

Figure 1. North 40 site magnetometry survey results and the proximity from North 40 site to Mound City. (Color online)

\section{History of Research}

Archaeologists first discovered the North 40 site in the 1960s through surface finds of diagnostic Hopewell bladelets (then named the "Drill Field" site). In 1982, Mark Lynott and a team from the National Park Service's Midwest Archeological Center completed a surface survey and limited excavations and concluded that the "relatively low density of artifacts" they collected represented a series of intermittent, short-term camps. They suggested that "the majority of archaeological remains [were] located in the plowzone" (Lynott 1982:4, 7; Lynott and Monk 1985:20).

A team from Hopewell Culture National Historical Park returned for additional research from 2007 to 2009 and in 2013 and 2017. In 2007, staff conducted a magnetic gradient survey using a Geoscan FM256 fluxgate gradiometer and tested discovered anomalies with a 3-inch bucket auger. Additionally, a $1 \times 1 \mathrm{~m}$ unit excavated over a portion of Structure 1 confirmed the presence of postholes. In 2008, Pit 1 was excavated along with a larger unit over the northwest corner of Structure 1 that revealed an additional four postholes (Figure 3). In 2009, a long trench $(2 \times 25 \mathrm{~m})$ crosscutting Structure 1 exposed additional postholes of the western wall and revealed poorly defined interior features. Pit 2 was also sampled in 2009, while Pit 3 was excavated in 2013. In 2017, a team from the German Archaeological Institute completed a landscape-scale magnetic gradient survey of the entire 15 ha field surrounding the site, revealing the presence of additional anomalies that are interpreted as two timber-post structures almost identical in size and orientation to Structure 1 (Figure 1). 


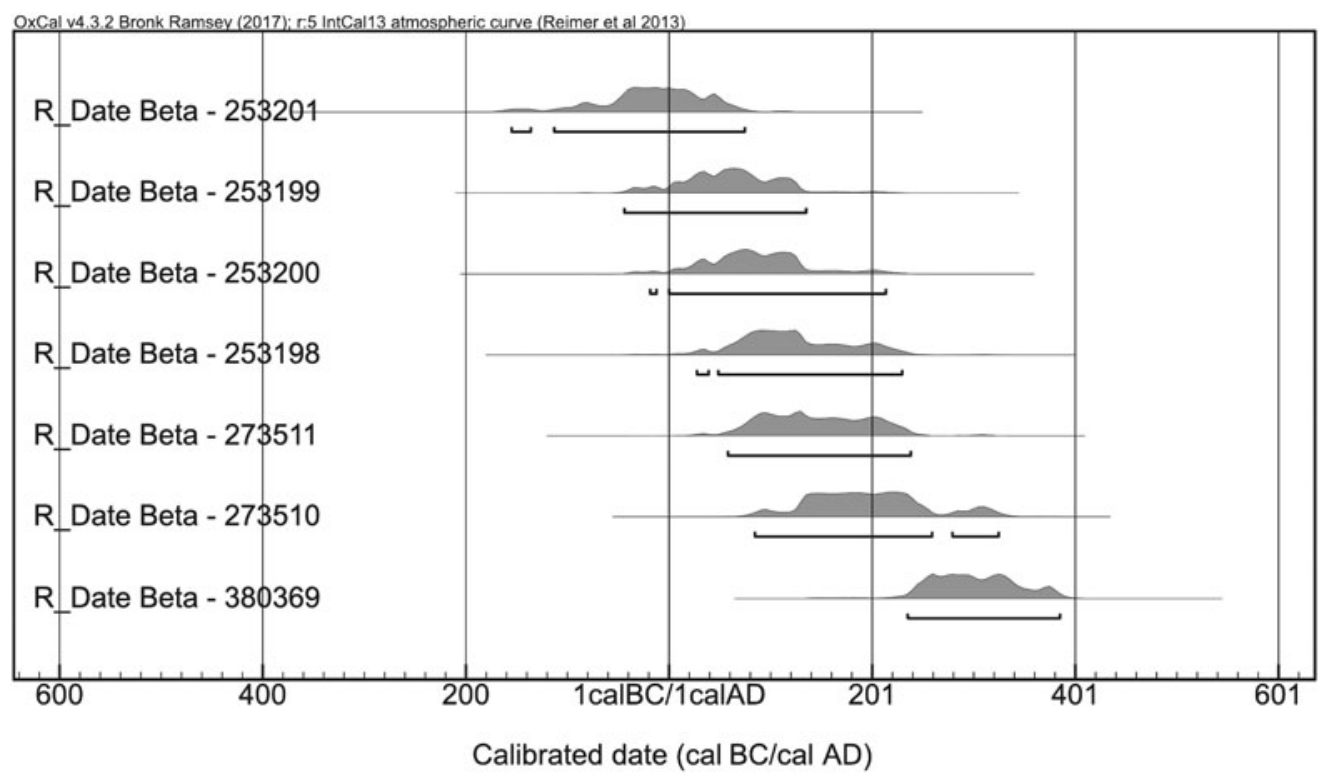

\begin{tabular}{|c|c|c|c|c|c|}
\hline Sample \# & Context & Material & RCYBP & 2 sigma calibrated results & $\delta^{13} \mathrm{C}(\%)$ \\
\hline Beta-253201 & Structure 1, Post 4 & Wood Charcoal (Carya sp.) & $2010 \pm 40$ & $156 \mathrm{BC}-\mathrm{AD} 75$ & -26.3 \\
\hline Beta - 253199 & Structure 1, Post 1 & Wood Charcoal (Carya sp.) & $1940 \pm 40$ & $45 \mathrm{BC}-\mathrm{AD} 136$ & -25.0 \\
\hline Beta -253200 & Structure 1, Post 2 & Wood Charcoal (Carya sp.) & $1920 \pm 40$ & $19 \mathrm{BC}-\mathrm{AD} 214$ & -24.8 \\
\hline Beta - 273511 & Pit 2 & Bark (Quercus sp.) & $1870 \pm 40$ & AD 59-325 & -25.4 \\
\hline Beta -273510 & Structure 1, Trench Post & Unidentified Bark & $1820 \pm 40$ & AD $85-325$ & -26.2 \\
\hline
\end{tabular}

Figure 2. Distribution and description of accelerator mass spectrometry dates from the North 40 site.

\section{Evidence for Craft Production at the North 40 Site}

The North 40 site possesses all the expected material remains to archaeologically identify craft production- "raw materials, debris, tools, and facilities associated with production" (Costin 1991:19). These classes of material correlates for craft production are unequally represented, yet each is presented here in full, as there is an expected difference in the archaeological visibility for each. Similarly, this information was included in order to document the dynamic interplay between the various material remains and facilities of craft production. The site also held a suite of material remains demonstrating that Scioto Hopewell craft production was embedded in ritualized and religious contexts. Together, these facilities and materials give the most complete picture of craft production of any site recorded in the CSV.

\section{Debris and Raw Materials}

Evidence of the raw materials utilized in craft production is represented mainly by production debris rather than unworked refuse. The majority of this debris and the strongest evidence for craft production at the North 40 site are the more than 200 unfinished bifaces and biface fragments in Pits 1 and 2. These were overwhelmingly of high-quality, nonlocal (ca. $300 \mathrm{~km}$ ) Harrison County chert (89\%; DeRegnaucourt and Georgiady 1998; Seeman 1975; Yerkes 2009a:8-9; Yerkes and Miller 2010:7-9). ${ }^{3}$ Pit 1 contained 22 early-stage and three late-stage bifaces and biface fragments. Pit 2 contained 180 early-stage and five late-stage bifaces and biface fragments (Figures 4 and 5 and Table 1; Yerkes 2009a; Yerkes and Miller 2010). Additional late-stage bifaces were discovered both in Pit 3 and beneath the plowzone within Structure 1. A technological and microwear analysis of these artifacts revealed 


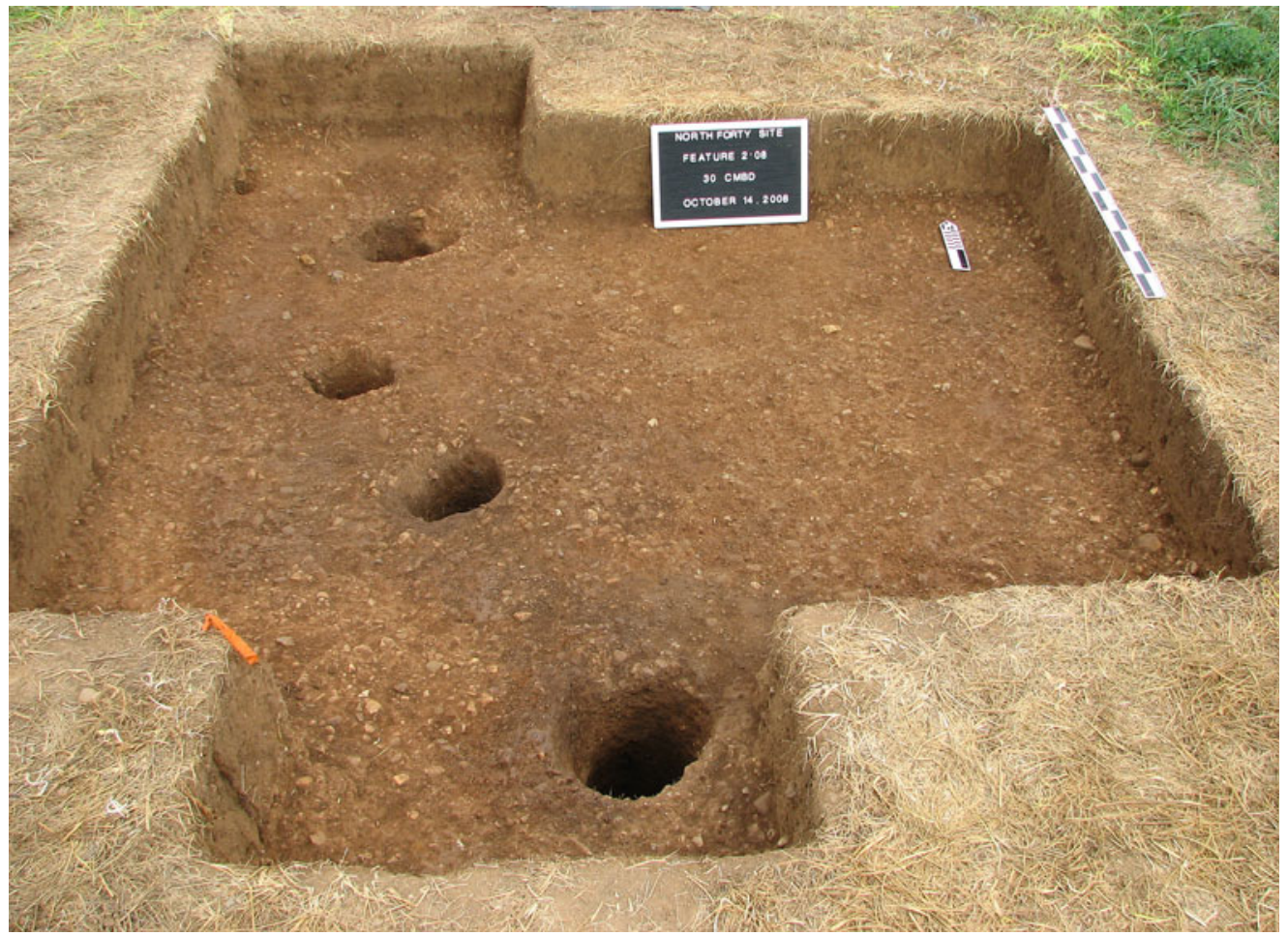

Figure 3. Postholes forming the southwest wall corner of Structure 1 (National Park Service photo). (Color online)

no visible signatures of use, hafting, or bag storage. Instead, each biface was either broken or rejected in manufacture due to raw material flaws or production errors that prevented proper thinning (Yerkes 2009a:6; Yerkes and Miller 2010:3). Thus, these bifaces are interpreted as rejects and failures, not as a cache.

A large sample of debitage $(n=3,742)$ was also recovered from all three pits, with the majority being flakes. The debitage was more thoroughly analyzed for Pits 1 and 2 to illuminate the reduction process as it relates to the numerous bifaces discovered in those pits. The assemblages from both pits are dominated by secondary reduction flakes, and both have debitage from the entire reduction sequence, likely produced during many knapping episodes. Analysis revealed that the majority of this debitage is consistent with bifacial reduction (Yerkes 2009a:7-8; Yerkes and Miller 2010:6-7). This, taken with the fact that the debitage from Pits 1 and 2 is dominated by the same chert type as the recovered early- and late-stage bifaces
(Harrison County), suggests that this debitage is the residual from the production of these bifaces. Moreover, the shared raw material type also supports that this material was being preferentially chosen, rather than possessing more material flaws (i.e., why there are so many rejects of this raw material and not others). The quantity of debitage along with the presence of cortex on many of the early-stage bifaces supports interpretation of the North 40 site as a primary production locale.

Given the skilled nature of Scioto Hopewell craftwork evident elsewhere, it is likely that these manufacturing failures and rejects represent only a fraction of total production. This in turn suggests that many hundreds or thousands more were finished and ultimately incorporated in the archaeological record of other locales, though there is presently insufficient evidence to suggest where. Many late-stage bifaces (often identified as "blanks," "preforms," or "cache blades") were interred with individuals in mounds such as Russell Brown Mound 2 


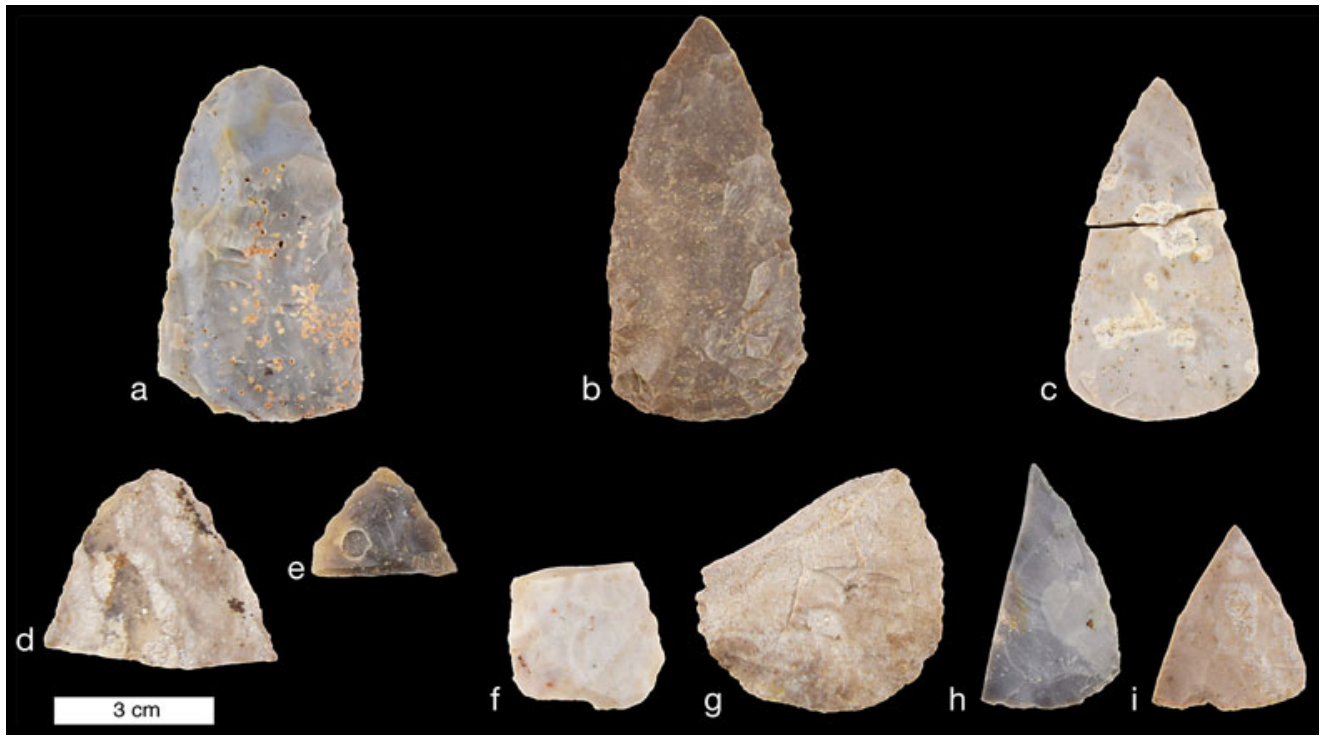

Figure 4. Late-stage bifaces (a-c) and biface fragments (d-i): (a) 42565; (b) 43745; (c) 49814; (d) 42587; (e) 43635; (f) 43956; (g) 43859; (h) 43981; (i) 42576. (Color online)
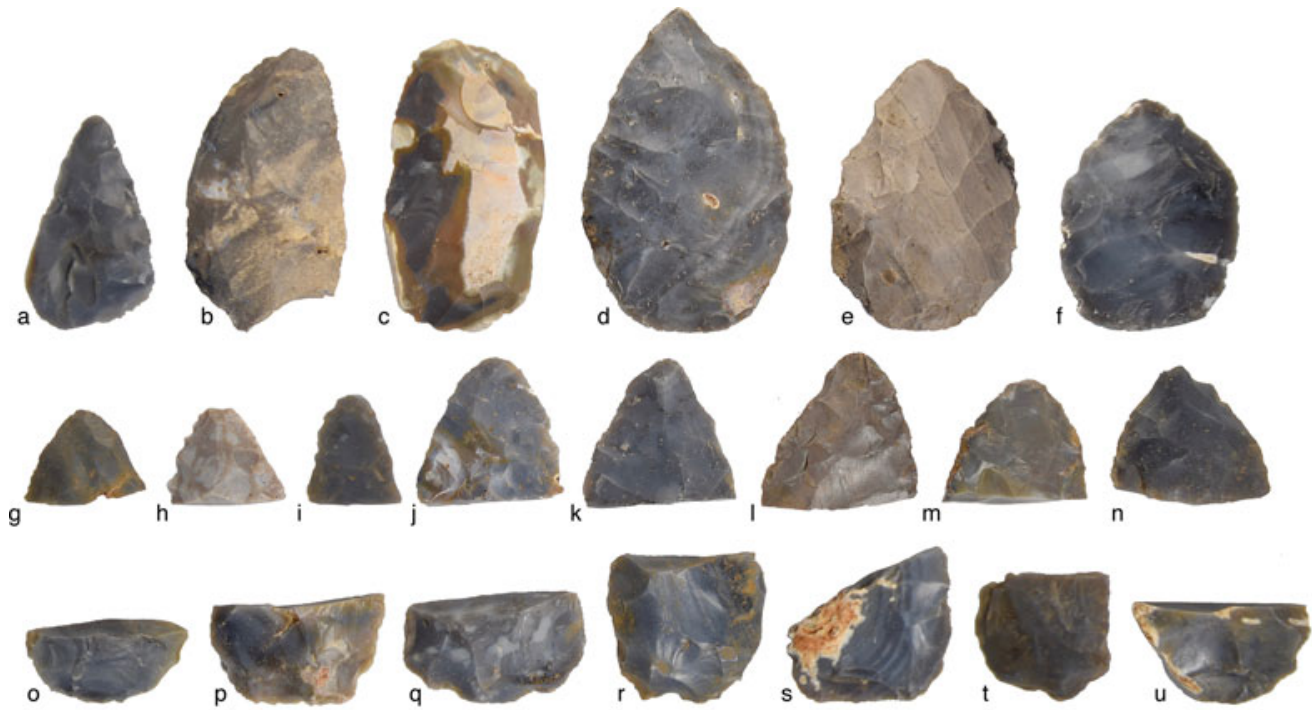

Figure 5. Early-stage bifaces and biface fragments: (a) 43970; (b) 43966; (c) 44002; (d) 43957; (e) 42546; (f) 43969; (g) 43926; (h) 42584; (i) 48928; (j) 44013; (k) 44011; (l) 43953; (m) 43952; (n) 43894; (o) 43994; (p) 43936; (q) 43961; (r) 43887; (s) 43893; (t) 43895; (u) 43927. (Color online)

(Seeman and Soday 1980:88) and Martin Mound (Mortine and Randles 1978:14) and in the embankment at Turner (Willoughby and Hooton 1922:12-13). Notably, an adult male individual interred in the southern embankment wall at
Mound City (Burial [feature] 20) was buried with 10 comparable late-stage bifaces (Figure 6; Brown 2012:186-188; Jeske and Brown 2012:255-256). Early-stage bifaces have also been recovered in mounds, often in large bundles 
Table 1. Material Remains from the North 40 Site (33RO338).

\begin{tabular}{|c|c|c|c|c|c|c|c|c|c|c|}
\hline \multirow[b]{2}{*}{ North 40 Site (33RO338) Artifact by Context } & \multicolumn{3}{|c|}{ Pits } & \multicolumn{6}{|c|}{ Structure 1} & \multirow[b]{2}{*}{ Total } \\
\hline & Pit 1 & Pit 2 & Pit 3 & Within Structure & Post 1 & Post 2 & Post 3 & Post 4 & Post 5 & \\
\hline \multicolumn{11}{|l|}{ Lithics } \\
\hline \multicolumn{11}{|l|}{ Tools } \\
\hline \multicolumn{11}{|l|}{ Bladelets } \\
\hline Complete & 0 & 5 & 4 & 0 & 0 & 0 & 0 & 0 & 0 & 9 \\
\hline Fragment & 0 & 17 & 17 & 2 & 0 & 0 & 0 & 0 & 0 & 36 \\
\hline \multicolumn{11}{|l|}{ Projectile Points } \\
\hline Lowe Cluster & 0 & 1 & 2 & 0 & 0 & 0 & 0 & 0 & 0 & 3 \\
\hline Unidentifiable & 0 & 2 & 1 & 0 & 0 & 0 & 0 & 0 & 0 & 3 \\
\hline Fragment & 0 & 0 & 2 & 0 & 0 & 0 & 1 & 0 & 0 & 3 \\
\hline \multicolumn{11}{|l|}{ Early-Stage Biface } \\
\hline Complete & 3 & 18 & 0 & 0 & 0 & 0 & 0 & 0 & 0 & 21 \\
\hline Fragment & 18 & 162 & 0 & 0 & 0 & 0 & 0 & 0 & 0 & 180 \\
\hline \multicolumn{11}{|l|}{ Late-Stage Biface } \\
\hline Complete & 1 & 1 & 1 & 0 & 0 & 0 & 0 & 0 & 0 & 3 \\
\hline Fragment & 2 & 4 & 0 & 1 & 0 & 0 & 0 & 0 & 0 & 7 \\
\hline Core & 0 & 0 & 1 & 0 & 0 & 0 & 0 & 0 & 0 & 1 \\
\hline Graver & 0 & 0 & 1 & 0 & 0 & 0 & 0 & 0 & 0 & 1 \\
\hline Unifacial & 0 & 0 & 1 & 0 & 0 & 0 & 0 & 0 & 0 & 1 \\
\hline Retouched/utilized flake & 0 & 3 & 3 & 0 & 0 & 0 & 0 & 0 & 0 & 6 \\
\hline Total & 24 & 213 & 33 & 3 & 0 & 0 & 1 & 0 & 0 & 274 \\
\hline \multicolumn{11}{|l|}{ Debitage } \\
\hline Shatter/blocky fragment & 91 & 484 & 38 & 1 & 0 & 0 & 0 & 0 & 0 & 613 \\
\hline Flake & 246 & 2,833 & 50 & 8 & 0 & 0 & 0 & 0 & 0 & 3,129 \\
\hline Total & 337 & 3,317 & 88 & 9 & 0 & 0 & 0 & 0 & 0 & 3,742 \\
\hline \multicolumn{11}{|l|}{ Ceramics } \\
\hline CCR tempered, thick-walled cordmarked (Cat. 1.1) & 1 & $238(2)$ & $274(5)$ & 0 & 0 & 0 & 0 & 0 & 0 & 513 \\
\hline $\mathrm{CCR}$, thin-walled cordmarked (Cat. 1.2) & 0 & $130(1)$ & $121(3)$ & 0 & 0 & 0 & 0 & 0 & 0 & 251 \\
\hline CCR, smoothed (Cat. 6) & 0 & 4 & $50(3)$ & 0 & 0 & 0 & 0 & 0 & 0 & 54 \\
\hline CCR, smoothed (Cat. 7) & 0 & $1(1)$ & $35(3)$ & 0 & 0 & 0 & 0 & 0 & 0 & 36 \\
\hline CCR, plain polished paste (Cat. 10) & 0 & 0 & $7(1)$ & 0 & 0 & 0 & 0 & 0 & 0 & 7 \\
\hline CCR, trailed over cordmarked (Cat. 11.1) & 0 & 0 & $2(1)$ & 0 & 0 & 0 & 0 & 0 & 0 & 2 \\
\hline CCR, simple stamped (Cat. 14) & 0 & 0 & $1(1)$ & 0 & 0 & 0 & 0 & 0 & 0 & 1 \\
\hline CCR, zone-decorated and crosshatched rim (Cat. 16) & 0 & $1(1)$ & 0 & 0 & 0 & 0 & 0 & 0 & 0 & 1 \\
\hline
\end{tabular}


CCR, wide-crosshatched rim (Cat. 16.b)

Limestone tempered, cordmarked (Cat. 18)

Sand tempered, smoothed surface (Cat. 23)

Sand tempered, cordmarked (Cat. 24)

Sand tempered, brushed (Cat. 25)

\section{Total}

\section{Floral Remains}

Wood Charcoal

Nutshell/meat

Acorn (Quercus spp.)

Black walnut (Juglans nigra)

Walnut Family (Juglandaceae)

Hazelnut (Corylus sp.)

Hickory (Carya sp.)$$
\text { Total }
$$

Seeds/Cultigen Parts

Chenopods (Chenopodium berlandieri)

Knotweed (Polygonum erectum)

Little barley (Hordeum pusillum)

Maygrass (Phalaris caroliniana)

Sunflower (Helianthus annuus)

Squash (Cucurbita pepo)

Bottle gourd (Lagenaria sicerara)

Cherry (Prunus serotina)

Grape (Vitis sp.)

Sumac (Rhus sp.)

Persimmon (Diospyros virginiana)

\section{Faunal Remains}

\section{Bones}

White-tail deer (Odocoileus virginianus)

Unidentified bird

Large unidentified mammal

Large-medium unidentified mammal

Unidentified mamma

Tools

Tool fragments

\begin{tabular}{|c|c|c|c|c|c|c|c|c|c|}
\hline 0 & 0 & $1(1)$ & 0 & 0 & 0 & 0 & 0 & 0 & 1 \\
\hline 0 & $1(1)$ & $3(1)$ & 0 & 0 & 0 & 0 & 0 & 0 & 4 \\
\hline 0 & 0 & $15(4)$ & 0 & 0 & 0 & 0 & 0 & 0 & 15 \\
\hline 0 & 0 & $3(2)$ & 0 & 0 & 0 & 0 & 0 & 0 & 3 \\
\hline 0 & 0 & $5(2)$ & 0 & 0 & 0 & 0 & 0 & 0 & 5 \\
\hline 1 & 375 & 517 & 0 & 0 & 0 & 0 & 0 & 0 & 893 \\
\hline 0 & 61 & 1,653 & 0 & 1,641 & 1,924 & 19 & 145 & 42 & 5,485 \\
\hline 0 & 0 & 596 & 0 & 0 & 0 & 0 & 0 & 0 & 596 \\
\hline 0 & 0 & 1,769 & 0 & 0 & 0 & 0 & 0 & 0 & 1,769 \\
\hline 0 & 0 & 48 & 0 & 0 & 0 & 0 & 0 & 0 & 48 \\
\hline 0 & 0 & 185 & 0 & 0 & 0 & 0 & 0 & 0 & 185 \\
\hline 0 & 0 & 773 & 0 & 0 & 0 & 0 & 0 & 2 & 775 \\
\hline 0 & 0 & 3,371 & 0 & 0 & 0 & 0 & 0 & 2 & 3,373 \\
\hline 0 & 0 & 1,715 & 0 & 0 & 0 & 0 & 0 & 0 & 1,715 \\
\hline 0 & 0 & 802 & 0 & 0 & 0 & 0 & 0 & 0 & 802 \\
\hline 0 & 0 & 1 & 0 & 0 & 0 & 0 & 0 & 0 & 1 \\
\hline 0 & 0 & 2,401 & 0 & 0 & 0 & 0 & 0 & 0 & 2,401 \\
\hline 0 & 0 & 1 & 0 & 0 & 0 & 0 & 0 & 0 & 1 \\
\hline 0 & 0 & 66 & 0 & 0 & 0 & 0 & 0 & 0 & 66 \\
\hline 0 & 0 & 1 & 0 & 0 & 0 & 0 & 0 & 0 & 1 \\
\hline 0 & 0 & 32 & 0 & 0 & 0 & 0 & 0 & 0 & 32 \\
\hline 0 & 0 & 210 & 0 & 0 & 0 & 0 & 0 & 0 & 210 \\
\hline 0 & 0 & 23 & 0 & 0 & 0 & 0 & 0 & 1 & 24 \\
\hline 0 & 0 & 74 & 0 & 0 & 0 & 0 & 0 & 0 & 74 \\
\hline 0 & 0 & 5,326 & 0 & 0 & 0 & 0 & 0 & 1 & 5,327 \\
\hline 0 & 0 & 37 & 0 & 0 & 0 & 0 & 0 & 0 & 37 \\
\hline 0 & 0 & 5 & 0 & 0 & 0 & 0 & 0 & 0 & 5 \\
\hline 0 & 0 & 1 & 0 & 0 & 0 & 0 & 0 & 0 & 1 \\
\hline 0 & 0 & 107 & 0 & 0 & 0 & 0 & 0 & 0 & 107 \\
\hline 0 & 0 & 3 & 0 & 0 & 0 & 0 & 0 & 0 & 3 \\
\hline 0 & 0 & 5 & 0 & 0 & 0 & 0 & 0 & 0 & 5 \\
\hline
\end{tabular}


Table 1. Continued.

\begin{tabular}{|c|c|c|c|c|c|c|c|c|c|c|}
\hline \multirow[b]{2}{*}{ North 40 Site (33RO338) Artifact by Context } & \multicolumn{3}{|c|}{ Pits } & \multicolumn{6}{|c|}{ Structure 1} & \multirow[b]{2}{*}{ Total } \\
\hline & Pit 1 & Pit 2 & Pit 3 & Within Structure & Post 1 & Post 2 & Post 3 & Post 4 & Post 5 & \\
\hline Total & 0 & 0 & 158 & 0 & 0 & 0 & 0 & 0 & 0 & 158 \\
\hline \multicolumn{11}{|l|}{ Exotics } \\
\hline Copper & 0 & 1 & 0 & 0 & 0 & 0 & 0 & 0 & 0 & 1 \\
\hline Mica & 0 & 57 & 0 & 0 & 0 & 0 & 0 & 0 & 0 & 57 \\
\hline Quartz crystal & 1 & 2 & 2 & 0 & 0 & 0 & 0 & 0 & 0 & 5 \\
\hline Obsidian & 0 & 1 & 0 & 0 & 0 & 0 & 0 & 0 & 0 & 1 \\
\hline Total & 1 & 61 & 2 & 0 & 0 & 0 & 0 & 0 & 0 & 64 \\
\hline
\end{tabular}

Notes: CCR = crystalline rock. Ceramic data presented as sherd count (vessel count). Categories are employed or modified from Brown [2012]. 


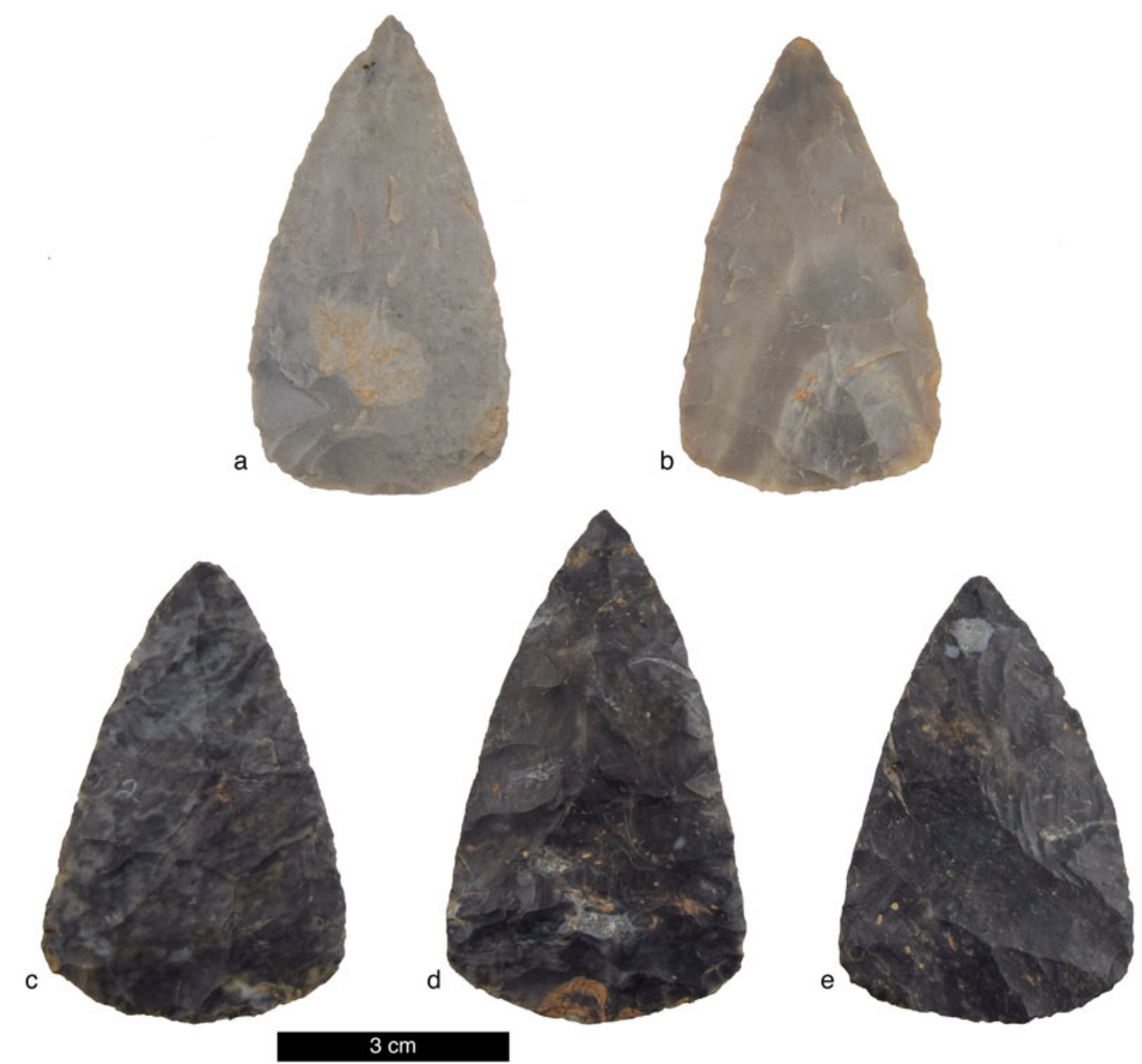

Figure 6. Late-stage bifaces from Burial 20 from the Southeast Embankment Wall at Mound City: (a) 585; (b) 582; (c) 584; (d) 550; (e) 583. (Color online)

such as the collection of more than 8,000 bifaces interred in Mound 2 of Hopewell Mound Group (Moorehead 1922:95-96; Squier and Davis 1848:158), almost 11,500 interred in the BaehrGust Mounds 1 and 2 in Illinois (Morrow 1991; Walton 1962:193-199), 10,000+ at the Crib Mound (Scheidegger 1968:145-147), and more than 3,000 at the GE Mound (Plunkett 1997) in southern Indiana. In each example, these assemblages of early-stage bifaces are dominated by cherts from southern Indiana and Illinois (e.g., Harrison County, Cobden-Dongola, Holland). These comparisons, taken with the overall nature of the North 40 site, suggest that these bifaces were produced for ultimate deposition in a ceremonial or mortuary setting.
The North 40 site produced an array of artifacts of exotic raw materials representing limited craft production debris (Figure 7). Included are one fragment of copper and 59 fragments of mica from Pit 2. The copper is a scrap of sheet copper - debris from the production of an artistic piece, rather than an awl, needle, or other tool of production (Bernardini and Carr 2005:631). Some of the mica pieces have cut edges indicative of craft production debris. Similarly, a total of five pieces of worked crystal quartz, including one flake, two blocky fragments, and the proximal end of a crystal quartz bladelet, were recovered from various contexts. With a hardness of 7 on the Mohs scale, crystal quartz represents a difficult, if wondrous craft material, but also a crafting tool of great utility. 

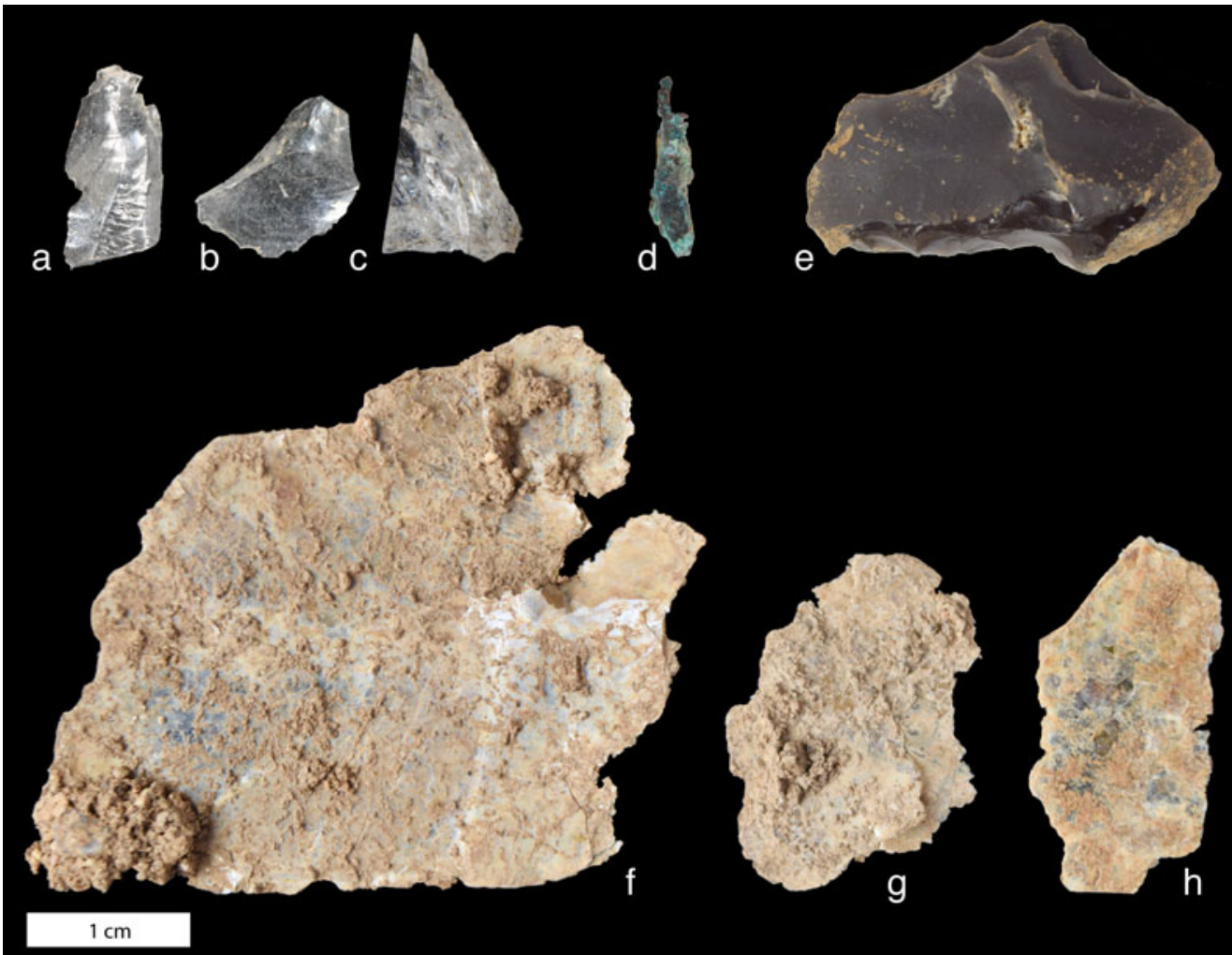

Figure 7. Sample of exotic raw materials recovered from North 40 site: (a) quartz crystal bladelet fragment (49808); (b) quartz crystal flake (42547); (c) quartz crystal blocky fragment (43643); (d) copper fragment (44005); (e) obsidian (43664); (f-h) mica fragments (left to right: 43851, 43853, 43884). (Color online)

Though there is not an overwhelming amount of exotic material debris from the North 40 site, this actually follows expectations. Many of the raw materials used in Scioto Hopewell craft production are nonlocal, making them costly to obtain and also endowing them with power (Bernardini and Carr 2005:631; Bradley 2000:81-84; Helms 1988, 1993:3). Copper crafts, in particular, involve many small pieces, such that debris was reused as rivets and other parts (Spielmann 2009:183). For obsidian, on the other hand, there seem to have been norms or restrictions regarding its deposition, perhaps due to the power inherent in the material or its necessary or honorary association with an important individual in death. The overwhelming majority of obsidian debitage has been discovered within Mound 11 at Hopewell Mound Group, and, more generally, only a few pieces of obsidian have been documented outside mound contexts (Shetrone 1926:39-43).
The only possible example of unaltered raw material for craft production is 14 bedstraw seeds (Galium sp.) that were recovered from Pit 3. The limited amount makes it possible that they entered the archaeological record incidentally through "seed rain" or a host of other mundane uses known for the plant itself (Leone 2013:12). Yet it is possible that they were brought in as a dyeing agent (Armitage and Jakes 2016; Jakes and Ericksen 2001).

\section{Tools}

Lamellar blades were the most numerous tool recovered and perhaps the primary tool used at the North 40 site. This core-and-blade technology constitutes an interregional horizon marker for Hopewellian engagement across the midcontinent, with great chronological and culturehistorical significance (Greber et al. 1981; Miller 2018; Odell 1994; Pi-Sunyer 1965; Yerkes 


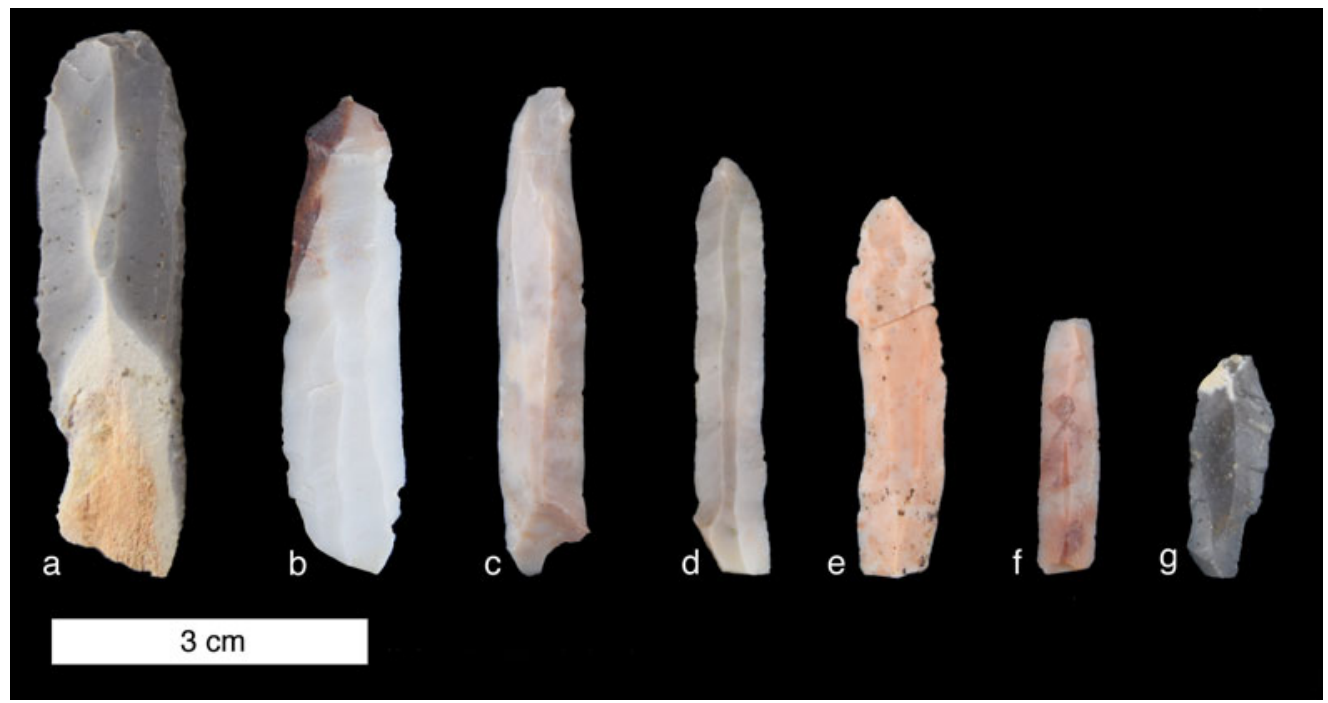

Figure 8. Sample of bladelets from the North 40 site: (a) 43864; (b) 49816; (c) 49721; (d) 49802; (e) 43650; (f) 49820; (g) 43630. (Color online)

1994). Pits 2 and 3 contained 43 lamellar blades (nine whole and 34 fragmented; Figure 8). A microwear analysis on the 22 bladelets or fragments from Pit 2 shows that nine $(40 \%)$ had been used for four different tasks, including cutting meat or fresh hide $(n=5)$, graving stone (or possibly cutting mica; $n=1$ ), scraping wood $(n=2)$, and sawing bone or antler $(n=1$; Yerkes and Miller 2010:10). Seven bladelets from the plowzone immediately above this pitthree with use-wear (two for stone and one for meat/hide) — speak further to the multifunctional utility of these tools (Yerkes and Miller 2010:10). These results are comparable to those of other microwear studies of bladelets at other sites (Miller 2014; Yerkes 2009b; see Yerkes and Miller 2010:Table 6) and are nearly identical to those from the Fort Ancient site. In each case, these tools are interpreted as having been used in diverse tasks associated with craft production (Miller 2014, 2015), and in this case, they represent the production of various crafts of multiple media. Interestingly, the raw material patterns for bladelets stand in stark contrast to the many bifaces, being dominated by Flint Ridge $(62 \%)$ rather than Harrison County $(6 \%$; Yerkes and Miller 2010:9-10).

A few other tools were recovered from Pits 2 and 3. Three hafted bifaces (one Lowe Cluster
[Justice 1987:212-213] and two unidentifiable) were discovered in Pit 2, while three hafted bifaces (two Lowe Cluster and one unidentifiable) and two fragments were found in Pit 3. From Pit 2, only the Lowe Cluster point showed any use-wear, with microwear consistent with cutting meat or fresh hide (Yerkes and Miller 2010:12). Similarly, two utilized flakes recovered from Pit 2 possessed use-wear, one having been used on hide and bone or antler and the other for scraping bone or antler. Another utilized flake of obsidian was recovered from Pit 2 with a retouched edge that appears to have been used extensively (Figure 7e). Pit 3 contained various other lithic tools, including one unifacial tool, one graver, three utilized flakes, and one amorphous core. Additionally, five fragments of worked bone, likely of two small tools used for perforation, were recovered (Coughlin 2019:4). The variety of mostly lithic tools along with the diverse uses identified through microwear analysis indicate that multiple craft production processes took place at the North 40 site.

\section{Facilities}

The facilities known from the North 40 site consist of at least three large timber-post structures and two perpendicular, linear arrangements of 
pits clustered in a small 1.75 ha area within the 15 ha survey area. These facilities contrast markedly in size, form, and spatial organization when compared with the best-documented domestic habitations in the CSV. No midden deposits or cooking features have been identified here, as would be expected for a domestic dwelling. The three tested pits (ranging in diameter from 2 to $4 \mathrm{~m}$ and in depth from 0.83 to $1 \mathrm{~m}$ ) were filled with refuse indicative of craft production and ceremonial gatherings and showed no signs of in situ burning, hot rock cookery, or other activities to suggest domestic uses before infilling. Structure 1, the only structure sampled in excavation, is a building of remarkable size, with walls approximately 16 and $18 \mathrm{~m}$ in length and with an interior area of $288 \mathrm{~m}^{2}$. Structure 1 is a substantial architectural construction, with posts averaging $27.50 \mathrm{~cm}$ in diameter and $86.75 \mathrm{~cm}$ in depth. As noted by Bruce Smith, "A general dichotomy of scale exists between Hopewellian habitation structures and those of the corporateceremonial sphere, with most of the known habitation structures appearing to have been occupied by 5 to 13 individuals" (1992:213), with a floor area less than $85 \mathrm{~m}^{2}$. Structure 1 far exceeds this threshold, being far larger than known Middle Woodland domestic structures in the CSV (Pacheco et al. 2009a, 2009b).

In fact, Structure 1 is one of the largest Scioto Hopewell structures yet discovered, excepting the multiroomed, corporate-ceremonial rectangular structures buried beneath the Edwin Harness Mound (33RO28; Greber 1983:15-17), Seip-Pricer Mound (33RO40; Shetrone and Greenman 1931:363-364), and Mound 25 at Hopewell Mound Group (Shetrone 1926:60). The interior area of Structure 1 is over twice that for the majority of submound charnel houses or shrine buildings documented at nearby Mound City (see Brown 2012:57-114). The formal design of Structure 1 suggests a special purpose: the perimeter of Structure 1 approximates a square with rounded corners (a "superellipse"4), recapitulating the form of the Mound City Group enclosure and several of the submound structures and prepared clay basins therein (Brown 2012:40-41; Mills 1922). Unfortunately, centuries of plowing have destroyed the floor and degraded the interior features. Wood charcoal from the postholes of this structure was almost exclusively hickory (Carya sp.; 99.3\%), nearly half of which was bark, suggesting that the ends of the posts were charred prior to insertion. Hickory, thus, seems to be the dominant architectural material for Structure 1-as is also known for the structure beneath the Edwin Harness Mound (Smart and Ford 1983:54). A single, roughly circular feature was detected in the southwest corner of the structure and was identified, though not sampled, during excavation. A gravelly fill was added near the western wall during the building's construction, perhaps for structural or drainage purposes. For these reasons, we do not know how the interior space was structured.

Pits 1, 2, and 3 are clearly associated with Structure 1 based on their proximity, planned arrangement in space, shared temporality, and artifactual similarities. Pits 2 and 3 contained craft production debris, raw materials, and tools, while Pit 1 contained only debris and raw materials. These pits are arranged in two perpendicular linear arrangements with the same azimuthal orientation as Structure 1 ( \pm 5 degrees). Artifact links include a single late-stage biface found immediately beneath the plowzone in Structure 1 that shares the same dimensions as those from the pits. This is the only other known late-stage biface from the site. Similarly, the plowzone sampled above Structure 1 (above the corner and in the trench cut across its center) contained debris (debitage, $n=161$ ) and tools (bladelets, $n$ =14; utilized flakes, $n=5$; other bifaces, $n=4$ ) much the same as discovered within all three pits.

Scholars (e.g., Baby and Langlois 1979; Spielmann 2009:183, 2013:149-150) have expected that at least some portion of Scioto Hopewell crafting occurred in workshops. The available data are not sufficient to identify Structure 1 as a special-purpose building devoted solely to craft production activities. However, the data do support the interpretation of the North 40 locale as a locus of craft production embedded in a ceremonial precinct, divorced from the domestic household sphere. The spatial clustering and alignment of the structures and pits, combined with artifact cross-ties and radiocarbon chronology, strongly suggest not only a functional association between all the identified 

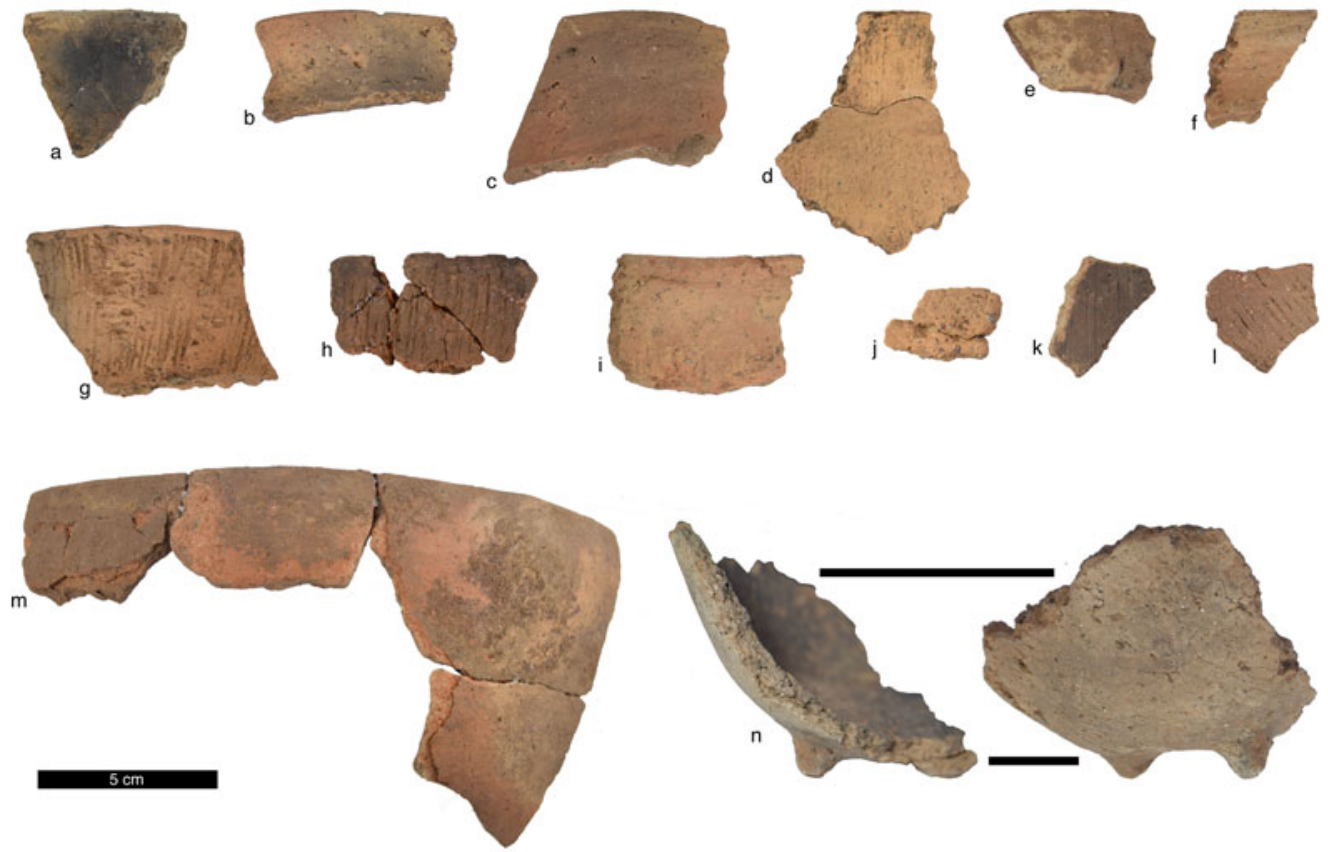

Figure 9. Ceramic assemblage from the North 40 site (Pit 2: f, i-j; Pit 3: a-e, g-h, k-n): (a) vessel 1 (49756); (b) vessel 2 (49832); (c) vessel 3 (49832); (d) vessel 4 (49845, 49833); (e) vessel 8 (49728); (f) vessel 2 (43755); (g) vessel 11 (49831); (h) vessel 12 (49831); (i) vessel 1 (43627); (j) vessel 5 (43609); (k) vessel 25 (49843); (l) vessel 20 (49741); (m) vessel 13 (49727, 44703, 49355); (n) vessel 23 (49807). (Color online)

facilities but that this spatial organization was planned. The size and formal design of the structures suggest corporate or communal rather than household-level uses. The location of the North 40 locale just $30 \mathrm{~m}$ north of the Mound City Group mound-and-earthwork complex strongly suggests that both should be considered together as elements within a larger ceremonial precinct. Taken together with the remains of associated ritual activity documented below, the North 40 site emerges as the best-documented materialization of the ritual mode of production (Spielmann 2002) in the Scioto Hopewell world.

\section{Remains of Associated Ritual Activity}

A host of evidence suggests that craft production at the North 40 site was itself ritualized and deeply embedded in Scioto Hopewell ceremonialism. Most notable is the remarkable ceramic assemblage ( $n=893$ sherds). We analyzed this assemblage utilizing the approach James Brown (2012:195-250) recently outlined for his study of the Mound City assemblage, in an effort to facilitate comparison and to avoid the main critique leveled at Olaf Prufer's (1968; Prufer and McKenzie 1965) long-standing typology: namely, that it misidentifies local and nonlocal vessels (Brown 2012:195-196; Hawkins 1996; Stoltman 2012).

The assemblage from the North 40 site, mostly from Pits 2 and 3, is dominated by local plain and cordmarked sherds $(95.7 \%)$. The 33 identified vessels (Pit $2=6$, Pit $3=27$ ) show much greater diversity, with 24 local vessels and nine "exotic" or nonlocal vessels (Figure 9). Vessels were identified mostly by unique rims but in some cases by sherd lots that were unequivocally unique either in their paste or in a combination of paste and surface treatment (Table 1; see also Brown 2012:197). The vessels are primarily jars, but two bowls and perhaps one lobed jar and one cylindrical jar (similar to a vessel from Turner-1; Prufer 1968:Plate 30) are present and suggest specialized food presentations or 
perhaps the consumption of special foodstuffs (cf. Crown and Hurst 2009). At least one vessel has carbonized residue fixed to its interior, adding support for the utilization of some of these vessels in food preparation. A few vessels have crosshatched rims or highly polished surfaces, and one vessel has tetrapodal supports, further suggesting specialized consumption and display.

The North 40 ceramic assemblage is similar to the assemblage from Mound City (Brown 2012:246) in being primarily a local assemblage with a minority of exotic vessels of likely Southeastern derivation. The nine nonlocal vessels were from Pit 3, with eight falling into Brown's (2012:234) class of "Crushed Sand Tempered, Exotic Pastes" with smoothed, cordmarked, and brushed finishes. ${ }^{5}$ Vessels of this paste are known from Mound City, and petrographic analysis suggests that they derived from the Blue Ridge region of the Appalachian Mountains (Stoltman 2012:405). The presence of nonlocal ceramics is unsurprising at this location given the known interregional circulation of ceramics (e.g., Ruby and Shriner 2005), but this stands in stark contrast to assemblages from Scioto Hopewell domestic sites (Prufer and McKenzie 1965). It is striking that these nonlocal ceramics seem to occur as only a few isolated sherds. The sherds seem to have been deliberately deposited, as Pit 3 demonstrated better-than-usual preservation (e.g., presence of many freshwater mussel shells and faunal materials) and does not seem to have accumulated slowly as a midden fill. That these nonlocal vessels, excepting the one bowl (vessel 13), were represented by only a few sherds is reminiscent of Feature 20 at the Duck's Nest sector of Pinson Mounds. There, sherds from 48 vessels of both local and nonlocal styles and origins were discovered in close proximity, with strong evidence that only portions of vessels were being deposited (Mainfort 2013:156-170). Mainfort interprets this assemblage as the product of performance "invoking and expressing a shared sense of friendship, certain shared beliefs, and common purpose" (2013:172). We tentatively interpret the exotic sherds from Pit 3 as being akin to Feature 20 of the Duck's Nest sector of Pinson Mounds, where these exotic sherds from Pit 3 represent the materialization of a relationship between multiple communities taking part in performative ritual activities.

A ceramic smoking pipe bowl was also discovered in Pit 3 (Figure 10). Only a very few examples of ceramic pipes are known from Ohio Hopewell sites, ${ }^{6}$ though about two dozen are known from Hopewell sites in Illinois and elsewhere. The bowl has a prominent rim and expanding medial portion, similar to a clay flat-platform-style pipe from Quitman County, Mississippi (Johnson 1968). Four similar examples executed in stone are known from the Illinois River Valley and are believed to date to the late Middle Woodland (cal. AD 250-400; Ken Farnsworth, personal communication 2014), consistent with the ${ }^{14} \mathrm{C}$ assay from Pit 3 (Figure 2).

A host of food remains were also discovered from the North 40 site. Unusually high densities of cultigens along with contextual associations with smoking paraphernalia and imported vessels led Leone (2014) to suggest that these are the remains of feasting. While Pit 2 had only three EAC seeds present, Pit 3 produced some of the densest concentrations of cultivated seed remains seen in any contemporaneous midcontinental context. Maygrass (Phalaris caroliniana; $18.48 \mathrm{n} / \mathrm{L}$ ), chenopods (Chenopodium berlandieri; $15.53 \mathrm{n} / \mathrm{L}$ ), and knotweed (Polygonum erectum; $8.27 \mathrm{n} / \mathrm{L})$ are especially well represented, with squash and gourd (Cucurbita pepo and Lagenaria sicerara), little barley (Hordeum pusillum), and sunflower (Helianthus annuus) also present (Table 1; Leone 2008, 2009, 2013:8-11). Only Pit 3 had well-preserved faunal remains, dominated by white-tail deer (Odocoileus virginianus), with the majority being forelimb elements (nearly 90\% being from the left side) and over half being ulnae ( minimum number of individuals $=5$; Coughlin 2019). The specificity of this assemblage, likely representing a desire for a specific "cut" of venison, along with the fact that all ulnae were from deer younger than 20 months, suggests that these are the remains of feasting (Coughlin 2019:5; Coughlin and Everhart 2019). If the comestible remains represent an event, it likely occurred in either the fall or winter, as evidenced by the floral and faunal assemblages, respectively (Leone 2013:14). This robust array of 

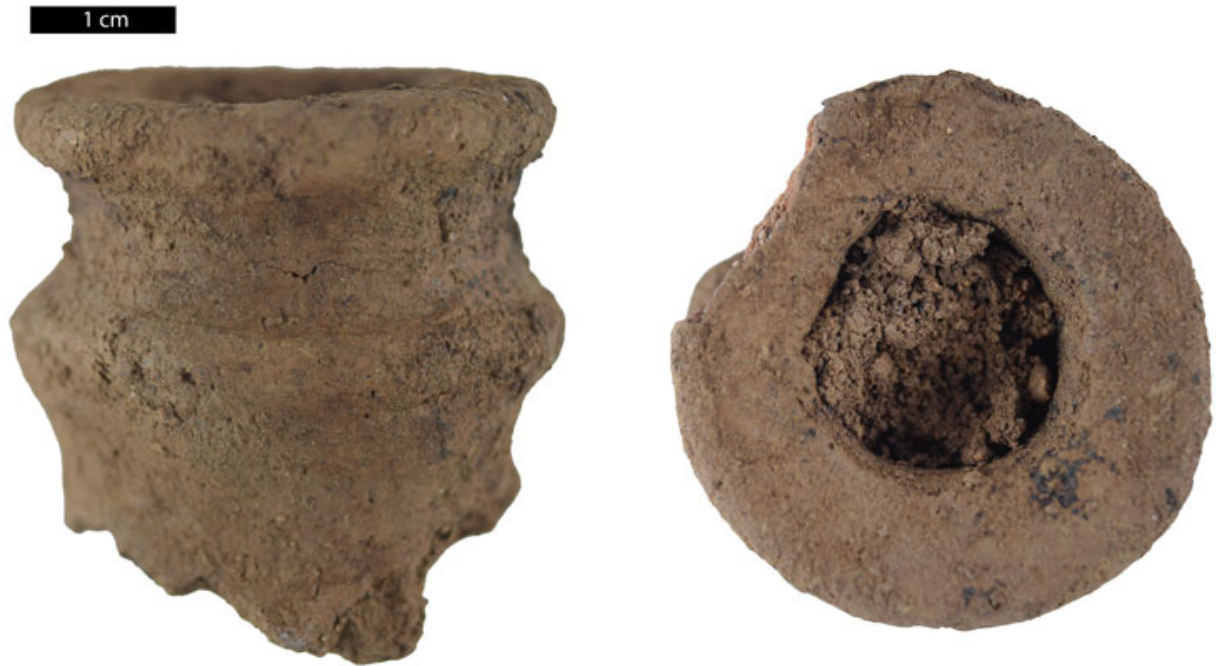

Figure 10. Ceramic pipe bowl fragment (49867): (left) profile view; (right) superior view. (Color online)

comestible remains, together with the specialized nonlocal vessels and smoking pipe, perhaps represents the residue of feasting among individuals drawn from diverse social groups, possibly of interregional scope.

\section{The Organization of Scioto Hopewell Craft Production}

The North 40 site has all the hallmarks of a craft production site embedded in a ceremonial precinct, with facilities consisting of three outsized structures and a series of pits containing raw materials, crafting debris, and tools (Costin 1991:19). The density and diversity of the floral remains (most notably the EAC seeds), the specificity of the faunal assemblage, the presence of vessels of unusual form and decoration (including nine that are nonlocal), and a smoking pipe suggest that craft production was a spiritually powerful activity. These materials were likely associated with what Seeman terms "preparatory elements of ritual," including feasting, smoking strong tobacco, and drinking "black drink" (2004:68). This finding is in keeping with recent research on the experiential meaning of earthworks (Bernardini 2004), in that it emphasizes that the processes and practices of creation for both the landscapes and objects of Scioto Hopewell ceremonialism were themselves religiously powerful.
Variation in the organization of craft production within small-scale societies results from the "scale of demand, the nature of use, the degree to which the materialization of ideology is controlled (DeMarrais et al. 1996) and the contexts in which populations ... aggregate" (Spielmann 2002:201). The North 40 site, with its outsized and formal architecture, abundant crafting debris and tools, and associations with smoking and fancy and imported serving vessels, demonstrates that Scioto craft production was at least predominantly located away from the domestic sphere, an anomaly within small-scale societies. The Scioto Hopewell case follows Spielmann's (2002:202) prediction that in societies where ceremonial centers are the locus for ritual aggregation, they may also host craft production. The North 40 site is immediately outside the Mound City enclosure, which was certainly a center for aggregation, and was likely part of an integrated ritual landscape. This organization of craft production accommodates the technical and esoteric knowledge required for production, the power inherent within many of these materials, the structuring of ceremonies around places of ritual aggregation, and, to a lesser extent, the logistics involved in acquiring the exotic raw materials for production and the demand for thousands of sacred and symbolically charged objects. Yet this organization almost certainly contained some 
variability, with some raw materials likely having been crafted at a household level. Mica debris, for example, has been found at a number of domestic sites within the CSV and beyond (Blosser 1996:58-59; Pacheco et al. 2009a, 2009b; Prufer 1965:98), perhaps suggesting that it was crafted within households because it is the simplest material to transform (Spielmann 2009:184).

The craft production remains and facilities from the North 40 site also offer an opportunity to further interpretations of other sites within the CSV. The Datum H (Pacheco et al. 2012) and Riverbank sites (33RO1059; Bauermeister 2010) at Hopewell Mound Group, Structure 1 at Hopeton (Lynott 2014:199-122), and the seven structures inside the Seip enclosure (Baby and Langlois 1979; Greber, ed. 2009) all bear some resemblance to the North 40 site, and further research may reveal a component of craft production at each. The case of the structures within the Seip enclosure is especially instructive, given the long-held notion of these structures as craft production locales (Baby and Langlois 1979). The recent reinterpretation of these structures cited an inability to link crafting debris with them and ultimately deemed the area instead as a "place of rituals" (Greber 2009b:171). While the taphonomic considerations are valid, it is important to note that places of ritual and craft workshops are not mutually exclusive spaces. In fact, the North 40 site demonstrates that Scioto Hopewell craft production locales were places of ritual. As such, a reanalysis of some of the aforementioned sites may conclude that they may well have been craft production sites.

Evidence from the North 40 site demonstrates that multiple media were being crafted at the same craft production locale. This includes at least mica, chert, and copper. Given that crafting style is media-specific (Seeman 2004:64), it is somewhat surprising that production locales were not also specific to raw material. Though it may be the case at Mound City, there is not yet enough data to suggest that craft production was practiced at, and specifically for, each earthwork. The crafting debris recovered from the North 40 site is in keeping with the emerging consensus that raw materials were obtained through direct acquisition (e.g., Bernardini and Carr 2005:632-634; Carr 2005b:579-586;
Seeman et al. 2019:1098; Spence and Fryer 2005:731; Spielmann 2009:180-181) and locally crafted (Braun 1986), although this was likely not the case everywhere for all materials. Recent research at the Garden Creek site in the Appalachian Summit has demonstrated that communities near the source of mica were unequivocally engaged in ritualized crafting (Wright and Loveland 2015). Four Copena-style steatite "Great Pipes" have long been known from the Seip-Pricer Mound (Shetrone and Greenman 1931:416-424), and recent petrographic analysis has documented ceramics from the same mound that are both stylistically and compositionally nonlocal, likely originating from various regions in the Southeast (Stoltman 2015:161-186). These examples, along with others, suggest that at least some completed objects were transported back to the CSV. Thus, the organization of craft production was variable, likely differing by raw materials, and was also perhaps time-transgressive.

While many aspects of Scioto Hopewell ceremonialism affected various social structures and daily life, the separation of craft production from the household has among the most important implications. While the temporality of crafting, and to what degree artisans were specialists or not, is yet unknown, their activities had to be economically offset. In this case, this is true to a far greater extent because craft production was removed from the domestic sphere. At some level, the subsistence economy had to be restructured. On one hand, it had to be intensified to support diverted labor (Spielmann 2002), and, on the other, patterns of distribution had to be altered to provide gathered comestibles to the North 40 site. This diverted labor goes beyond just the artisans themselves and likely includes different personnel responsible for clearing the old-growth forest in this area and constructing the massive architectural structures. Evidence also suggests that artisans were perhaps feasting at the site as part of the spiritually charged crafting processes, making this even more economically demanding.

The organization of craft production outside the domestic sphere also added to the overall complexity of settlement systems, adding a node to the network that at least a small portion of the population had to travel to, occupy, and 
maintain. It is yet unseen how Scioto Hopewell leaders gained and wielded power to schedule, plan, and organize the complex ceremonialism, but the separation of craft production from other arenas of daily life certainly added to this complexity. Similarly, artisans must have held unique positions within society, adding complexity to the overall sociopolitical organization (Brandt 1977; Helms 1993). Specifically, this increased the number of social roles and diversified social identities. It also forged a number of new relationship types divorced from kin relations, as is typical in small-scale societies (Spielmann 2002), such as master and apprentice, producer and supplicant, and host and visitor.

\section{Conclusion}

Scioto Hopewell rituals centered around the construction of massive earthen monuments and the production of a tremendous quantity of ornate crafts. The organization of craft production beyond the household at the North 40 site is an unusual example among small-scale societies, thus adding to the known complexity of ritual economies of small-scale societies (see Spielmann 2002). Artists possessing esoteric knowledge crafted intricately designed objects at this locale using multiple powerful materials (DeBoer 2004:99; Seeman et al. 2019; Spielmann 2002:198, 2009:179) on a grand scale. Moreover, evidence from the site shows that craft production was not simply a prerequisite to Hopewellian ceremonialism but likely integral to a ritual complex involving feasting and smoking among probably a host of other ritual practices. The implications of craft production organized and operationalized in these fashions highlight the importance of understanding the social dynamics of small-scale societies through the framework of ritual economy.

Acknowledgments. This research was supported by the National Park Service. In particular, Jennifer PedersonWeinberg and Kathleen Brady began this research at Hopewell Culture National Historical Park. Thanks also go to the many crew members who carried out the fieldwork at the North 40 site. Magnetic gradient data resulted from a collaboration between the National Park Service, Deutsches Archäologisches Institut (special thanks to Friedrich Lüth and Rainer Komp), SENSYS, Bournemouth University, and
Ohio Valley Archaeology Inc. John Klausmeyer offered assistance with the creation of the figures. We thank Jennifer Larios for translating the abstract into Spanish. This article was dramatically improved by the editorial support of Lynn Gamble and by the comments offered by Alice Wright, Mark Seeman, and two anonymous reviewers. We also appreciate the helpful feedback provided by Hannah Hoover, Martin Menz, and Brian Stewart on various drafts of this article.

Data Availability Statement. All analyzed materials, analytical tables, and specialist reports are housed at Hopewell Culture National Historical Park, Chillicothe, Ohio.

\section{Notes}

1. This region, under different names (Scioto-Paint Creek confluence [e.g., Ruby et al. 2005; Seeman and Branch 2006] or Scioto Ceremonial Zone [DeBoer 2010]), has been used as a unique scale of analysis for various reasons. Most important, as noted by Greber, "the Early and Middle Woodland local culture trajectories in other tributaries of the Central Ohio Valley are demonstrably different from that of the Central Scioto" (1991:3). Herein, this region is adopted to minimize the influence of variability across space (though topography will, of course, be of consideration). Likewise, "Scioto Hopewell" will be utilized to refer to sites within this region, whereas "Ohio Hopewell" will refer to sites in other drainages throughout Ohio.

2. Many structures were discovered in the "Interior Household Cluster" (Connolly 1997; Lazazzera 2004), yet these structures are interpreted as having both domestic and ceremonial functions. While craft production could have happened within houses and households, evidence elsewhere at the site suggests otherwise, and the association of these bladelets with these habitations (Miller 2015) is not sufficient evidence for this interpretation.

3. While Yerkes (2009a; Yerkes and Miller 2010) identified this material as Harrison County, it is also visually consistent with other blue-gray cherts from southern Indiana and Illinois (Morrow et al. 1992), most notably the black variety of Holland chert commonly referred to as Ferdinand (DeRegnaucourt and Georgiady 1998:100-101).

4. A superellipse is a geometric form made famous by the Danish poet Piet Hein as the perfect harmonization of circle and square and incorporated into the design of everything from coffee tables, to dinner plates, to Stockholm's central square, Sergels Torg (Gardner 1965).

5. Though Brown labels these "sand tempered," he allows that some of these vessels have pastes containing "fine crushed grit that is sand-like in appearance" (2012:234).

6. We are only aware of two other Ohio Hopewell ceramic platform pipes. Neither of the bowls of these pipes share stylistic similarity with the North 40 pipe. These pipes were recovered by a local collector near the Alspach Mound (Fairfield County, Ohio), near two Hopewell ceramic rim sherds (Murphy 1975:219-221, Figure 51).

\section{References Cited}

Abrams, Elliot M.

2009 Hopewell Archaeology: A View from the Northern Woodlands. Journal of Archaeological Research 17:169-204. 
Armitage, Ruth Ann, and Kathryn A. Jakes

2016 Sequencing Analytical Methods for Small Sample Dating and Dye Identification of Textile Fibers: Application to a Fragment from Seip Mound Group, Ohio. Midcontinental Journal of Archaeology 41:26-40.

Baby, Raymond S., and Suzanne M. Langlois

1979 Seip Mound State Memorial: Nonmortuary Aspects of Hopewell. In Hopewell Archaeology: The Chillicothe Conference, edited by David S. Brose and N'omi Greber, pp. 16-18. Kent State University Press, Kent, Ohio.

Bauermeister, Ann C.

2010 Feature Finds from the Riverbank Site, 33RO1059. Hopewell Archeology: The Newsletter of Hopewell Archeology in the Ohio River Valley 7:47-52.

Bernardini, Wesley

2004 Hopewell Geometric Earthworks: A Case Study in the Referential and Experiential Meaning of Monuments. Journal of Anthropological Archaeology 23:331-356.

Bernardini, Wesley, and Christopher Carr

2005 Hopewellian Copper Celts from Eastern North America: Their Social and Symbolic Significance. In Gathering Hopewell: Society, Ritual, and Ritual Interaction, edited by Christopher Carr and D. Troy Case, pp. 624-647. Springer, New York.

Blosser, Jack K.

1996 The 1984 Excavation at 12D29S: A Middle Woodland Village in Southeastern Indiana. In A View from the Core: A Synthesis of Ohio Hopewell Archaeology, edited by Paul J. Pacheco, pp. 54-69. Ohio Archaeological Council, Columbus.

Bradley, Richard

2000 An Archaeology of Natural Places. Routledge, London.

Brandt, Elizabeth

1977 The Role of Secrecy in a Pueblo Society. In Flowers of the Wind: Papers on Ritual, Myth, and Symbolism in Californian and the Southwest, edited by Thomas C. Blackburn, pp. 11-28. Anthropological Paper 8. Ballena Press, Socorro, Texas.

Braun, David P.

1986 Midwestern Hopewellian Exchange and Supralocal Interaction. In Peer PolityInteraction and Socio-political Change, edited by Colin Renfrew, and John F. Cherry, pp. 117-126. Cambridge University Press, Cambridge.

Bronk Ramsey, Christopher

2017 OxCal 4.3. Electronic document, https://c14.arch. ox.ac.uk/oxcal/OxCal.html, accessed November 29, 2019.

Brown, James A.

2012 Mound City: The Archaeology of a Renown Ohio Hopewell Mound Center. Special Report 6. Midwest Archeological Center, National Park Service, Lincoln, Nebraska.

Brumfiel, Elizabeth M., and Timothy K. Earle

1987 Specialization, Exchange, and Complex Societies. In Specialization, Exchange, and Complex Societies, edited by Elizabeth M. Brumfiel and Timothy K. Earle, pp. 1-9. Cambridge University Press, Cambridge.

Byers, A. Martin

2004 The Ohio Hopewell Episode: Paradigm Lost, Paradigm Gained. University of Akron Press, Akron, Ohio.
2011 Sacred Games, Death, and Renewal in the Ancient Eastern Woodlands: The Ohio Hopewell System of Cult Sodality Hierarchies. AltaMira Press, Lanham, Maryland.

Carr, Christopher

2005a Scioto Hopewell Ritual Gatherings: A Review and Discussion of Previous Interpretations and Data. In Gathering Hopewell: Society, Ritual, and Ritual Interaction, edited by Christopher Carr and D. Troy Case, pp. 463-532. Springer, New York.

2005b Rethinking Interregional Hopewellian "Interaction." In Gathering Hopewell: Society, Ritual, and Ritual Interaction, edited by Christopher Carr and D. Troy Case, pp. 575-623. Springer, New York.

2008a Environmental Setting, Natural Symbols, and Subsistence. In The Scioto Hopewell and Their Neighbors: Bioarchaeological Documentation and Cultural Understanding, by D. Troy Case and Christopher Carr, pp. 41-100. Springer, New York.

2008b Social and Ritual Organization. In The Scioto Hopewell and Their Neighbors: Bioarchaeological Documentation and Cultural Understanding, by D. Troy Case and Christopher Carr, pp. 151-287. Springer, New York.

Carr, Christopher, and D. Troy Case

2005 The Nature of Leadership in Ohio Hopewellian Societies: Role Segregation and the Transformation from Shamanism. In Gathering Hopewell: Society, Ritual, and Ritual Interaction, edited by Christopher Carr and D. Troy Case, pp. 177-237. Springer, New York.

Carr, Christopher, and Robert Mazlowski

1995 Cordage and Fabrics: Relating Form, Technology, and Social Processes. In Style, Society, and Person, edited by Christopher Carr and Jill Neitzel, pp. 297-343. Plenum, New York.

Carr, Christopher, and Anna Novotny

2015 Arrangement of Human Remains and Artifacts in Scioto Hopewell Burials: Dramatic Rituals or Ritual Dramas? In Transforming the Dead: Culturally Modified Bone in the Prehistoric Midwest, edited by Eve A. Hargrave, Shirley J. Schermer, Kristin M. Hedman, and Robin M. Lillie, pp. 79-100. University of Alabama Press, Tuscaloosa.

Carr, Christopher, Rex Weeks, and Mark Bahti

2008 The Functions and Meanings of Ohio Hopewell Ceremonial Artifacts in Ethnohistorical Perspective. In The Scioto Hopewell and Their Neighbors: Bioarchaeological Documentation and Cultural Understanding, by D. Troy Case and Christopher Carr, pp. 501-521. Springer, New York.

Case, D. Troy, and Christopher Carr

2008 The Scioto Hopewell and Their Neighbors: Bioarchaeological Documentation and Cultural Understanding. Springer, New York.

Childe, V. Gordon

1950 The Urban Revolution. Town Planning Review 21:3-17.

Connolly, Robert P.

1997 The Evidence for Habitation at the Fort Ancient Earthworks, Warren County, Ohio. In Ohio Hopewell Community Organization, edited by William Dancey and Paul Pacheco, pp. 251-281. Kent State University Press, Kent, Ohio.

Coon, Matthew S.

2009 Variation in Ohio Hopewell Political Economy. American Antiquity 74:49-76. 
Costin, Cathy L.

1991 Craft Specialization: Issues in Defining, Documenting and Explaining the Organization of Production. In Archaeological Method and Theory, Vol. 3, edited by Michael B. Schiffer, pp. 1-56. University of Arizona Press, Tucson.

1998 Introduction: Craft and Social Identity. In Craft and Social Identity, edited by Rita P. Wright and Cathy L. Costin, pp. 3-17. Archaeological Papers No. 8. American Anthropological Association, Arlington, Virginia.

Coughlin, Sean P.

2019 Analysis of Faunal Remains from Feature 2010-1, North-40 Tract Site (33Ro338), Ross County, Ohio. AAL Project \#19SP001. Report submitted to Hopewell Culture National Historical Park. Copies available from Hopewell Culture National Historical Park, Chillicothe, Ohio.

Coughlin, Sean P., and Timothy D. Everhart

2019 Evidence of Hopewell Feasting in a Non-mound Context. Paper presented at the Fall Meeting of the Ohio Archaeological Council, Columbus.

Cowan, C. Wesley

1996 Social Implications of Ohio Hopewell Art. In A View from the Core: A Synthesis of Ohio Hopewell Archaeology, edited by Paul J. Pacheco, pp. 128-149. Ohio Archaeological Council, Columbus.

Crown, Patricia L., and Jeffery Hurst

2009 Evidence of Cacao Use in the Prehispanic American Southwest. PNAS 106:2110-2113.

Dancey, William S., and Paul J. Pacheco (editors)

1997 Ohio Hopewell Community Organization. Kent State University Press, Kent, Ohio.

DeBoer, Warren R.

2004 Little Bighorn on the Scioto: The Rocky Mountain Connection to Ohio Hopewell. American Antiquity 69:85-108.

2010 Strange Sightings on the Scioto. In Hopewell Settlement Patterns, Subsistence, and Symbolic Landscapes, edited by A. Martin Byers and Dee Anne Wymer, pp. 165-198. University Press of Florida, Gainesville.

DeMarrais, Elizabeth, Luis Jaime Castillo, and Timothy K. Earle

1996 Ideology, Materialization, and Power Strategies. Current Anthropology 37:15-31.

DeRegnaucourt, Tony, and Jeff Georgiady

1998 Prehistoric Chert Types of the Midwest. Occasional Monographs in Archaeology 7. Upper Miami Valley Archaeological Research Museum, Arcanum, Ohio.

Dragoo, Don W., and Charles F. Wray

1964 Hopewell Figurine Rediscovered. American Antiquity 30:195-199.

Emerson, Thomas E., Kenneth B. Farnsworth, Sarah U. Wisseman, and Randall E. Hughes

2013 The Allure of the Exotic: Reexamining the Use of Local and Distant Pipestone Quarries in Ohio Hopewell Pipe Caches. American Antiquity 78:48-67.

Gardner, Martin

1965 The Superellipse: A Curve that Lies between the Ellipse and the Rectangle. Scientific American 213:222-238.

Giles, Bretton

2010 Sacrificing Complexity: Renewal through Ohio Hopewell Rituals. In Ancient Complexities: New Perspectives in Precolumbian North America, edited by
Susan M. Alt, pp. 73-95. University of Utah Press, Salt Lake City.

2019 The Genealogical Connections between Particular Hopewellian and Mississippian Avian Motifs and Themes. In Encountering Hopewell in the Twenty-First Century, Ohio and Beyond, edited by Brian G. Redmond, Bret J. Ruby, and Jarrod Burks, pp. 231-264. University of Akron Press, Akron, Ohio.

Greber, N'omi B.

1979 Variations in Social Structure of Ohio Hopewell Peoples. Midcontinental Journal of Archaeology 4:35-78.

1983 Recent Excavations at the Edwin Harness Mound: Liberty Works, Ross County, Ohio. MCJA Special Paper No. 5. Kent State University Press, Kent, Ohio.

1991 A Study of Continuity and Contrast between Central Scioto Adena and Hopewell Sites. West Virginia Archaeologist 43:1-26.

2009a Stratigraphy and Chronology in the 1971-1977 Field Data. Midcontinental Journal of Archaeology 34:19-52.

2009b Final Data and Summary Comments. Midcontinental Journal of Archaeology 34:171-186.

Greber, N'omi B. (editor)

2009 Re-interpretation of a Group of Hopewell Low Mounds and Structures, Seip Earthworks, Ross County, Ohio. Special issue, Midcontinental Journal of Archaeology 34

Greber, N'omi, Richard Davis, and Ann DuFresne

1981 The Micro Component of the Ohio Hopewell Lithic Technology: Bladelets. Annals of the New York Academy of Sciences 376:489-528.

Greber, N'omi B., and Katherine Ruhl

1989 The Hopewell Site. Westview Press, Boulder, Colorado.

Griffin, James B.

1952 Culture Periods in Eastern United States Archeology. In Archeology of Eastern United States, edited by James B. Griffin, pp. 352-364. University of Chicago Press, Chicago.

1967 Eastern North American Archaeology: A Summary. Science 156:175-191.

Hall, Robert L.

1979 In Search of the Ideology of the Adena-Hopewell Climax. In Hopewell Archaeology: The Chillicothe Conference, edited by David S. Brose and N'omi Greber, pp. 258-265. Kent State University Press, Kent, Ohio.

Hawkins, Rebecca A.

1996 Revising the Ohio Middle Woodland Ceramic Typology: New Information from the Twin Mounds West Site. In A View from the Core: A Synthesis of Ohio Hopewell Archaeology, edited by Paul J. Pacheco, pp. 70-91. Ohio Archaeological Council, Columbus.

Helms, Mary W.

1988 Ulysses' Sail: An Ethnographic Odyssey of Power, Knowledge, and Geographic Distance. Princeton University, Princeton, New Jersey.

1993 Craft and the Kingly Ideal. University of Texas Press, Austin.

Hill, Mark A., Mark F. Seeman, Kevin C. Nolan, and Laure Dussubieux

2018 An Empirical Evaluation of Copper Procurement and Distribution: Elemental Analysis of Scioto Valley Hopewell Copper. Archaeological and Anthropological Sciences 10:1193-1205. 
Hughes, Richard

2006 The Sources of Hopewell Obsidian: Forty Years after Griffin. In Recreating Hopewell, edited by Douglas K. Charles and Jane E. Buikstra, pp. 361-375. University Press of Florida, Gainesville.

Jakes, Kathryn A., and Annette G. Ericksen

2001 Prehistoric Use of Sumac and Bedstraw as Dye Plants in Eastern North America. Southeastern Archaeology 20:56-66.

Jeske, Robert, and James A. Brown

2012 Chipped Stone Assemblage. In Mound City: The Archaeology of a Renown Ohio Hopewell Mound Center, edited by James B. Brown, pp. 251-296. Special Report 6. Midwest Archeological Center, National Park Service, Lincoln, Nebraska.

Johnson, Glenn

1968 A Burial from Quitman County. Newsletter of Mississippi Archaeology Association 3:2-3.

Justice, Noel D.

1987 Stone Age Spear and Arrow Points of the Midcontinental and Eastern United States. Indiana University Press, Bloomington.

Lazazzera, Adrienne

2004 Hopewell Household Variation at the Fort Ancient Site. In The Fort Ancient Earthworks: Prehistoric Lifeways of the Hopewell Culture in Southwestern Ohio, edited by Robert Connolly and Bradley T. Lepper, pp. 84-106. Ohio Historical Society, Columbus.

Leone, Karen L.

2008 Archaeobotanical Analysis of the North Forty Site (33Ro338) at Mound City in Ross County, Ohio. Report submitted to Hopewell Culture National Historical Park. Copies available from Hopewell Culture National Historical Park, Chillicothe, Ohio.

2009 Archaeobotanical Analysis of the North Forty Site (33Ro338) at Mound City in Ross County, Ohio: 2009 Field Season. Report submitted to Hopewell Culture National Historical Park. Copies available from Hopewell Culture National Historical Park, Chillicothe, Ohio.

2013 Paleoethnobotanical Analysis of the North 40 Site (33Ro338) at Mound City in Ross County, Ohio: Results from the 2013 Investigations. Report submitted to Hopewell Culture National Historical Park. Copies available from Hopewell Culture National Historical Park, Chillicothe, Ohio.

2014 Botanical Evidence of Hopewell Feasting? A Case Study from Central Ohio. Paper presented at the 58th Annual Meeting of the Midwest Archaeological Conference, Champaign-Urbana, Illinois.

Lepper, Bradley T., Richard W. Yerkes, and Williams H. Pickard

2001 Prehistoric Flint Procurement Strategies at Flint Ridge, Licking County, Ohio. Midcontinental Journal of Archaeology 26:53-78.

Lynott, Mark J.

1982 An Archaeological Investigation of an Area Adjacent to Mound City Group National Monument: A Preliminary Report. Report on file at Hopewell Culture National Historical Park, Chillicothe, Ohio.

2014 Hopewell Ceremonial Landscapes of Ohio: More than Mounds and Geometric Earthworks. Oxbow, Oxford.

Lynott, Mark J., and Susan M. Monk

1985 Mound City, Ohio, Archeological Excavations. Occasional Studies in Anthropology No. 12. Midwest
Archeological Center, National Park Service, Lincoln, Nebraska.

Mainfort, Robert, C., Jr.

2013 Pinson Mounds: Middle Woodland Ceremonialism in the Midsouth. University of Arkansas Press, Fayetteville.

Malinowski, Bronislaw

1935 Coral Gardens and Their Magic. George Allen and Unwin, London.

Miller, G. Logan

2014 Ritual, Craft, and Economy in Ohio Hopewell: An Examination of Two Earthworks on the Little Miami River. PhD dissertation, Department of Anthropology, Ohio State University, Columbus.

2015 Ritual Economy and Craft Production in Small-Scale Societies: Evidence from Microwear Analysis of Hopewell Bladelets. Journal of Anthropological Archaeology 39:124-138.

2018 Hopewell Bladelets: A Bayesian Radiocarbon Analysis. American Antiquity 83:224-243.

Mills, William C.

1921 Flint Ridge. Certain Mounds and Village Sites in Ohio 3. Ohio Archæological and Historical Society, Columbus.

1922 Explorations of the Mound City Group. Ohio Archaeological and Historical Quarterly 31:423-584.

Minich, Frances J.

2004 Hopewell Stone Carvers: Reinterpreting the Roles of Artist and Patron. PhD dissertation, Department of Art History, Virginia Commonwealth University, Richmond.

Moorehead, Warren K.

1922 The Hopewell Mound Group of Ohio. Publication 211, Anthropological Series, Vol. 6, No. 5. Field Museum of Natural History, Chicago.

Morrow, Carol A

1991 Observation on the Baehr Mounds Chert "Disks": The American Museum of Natural History Collections. Illinois Archaeology 3:77-92.

Morrow, Carol A., J. Michael Elam, and Michael D. Glascock 1992 The Use of Blue-Gray Chert in Midwestern Prehistory. Midcontinental Journal of Archaeology 17:166-197.

Mortine, Wayne A., and Doug Randles

1978 The Martin Mound: An Extension of the Hopewell Interaction Sphere into the Walhonding Valley of Eastern Ohio. Occasional Papers in Muskingum Valley Archaeology No. 10. Muskingum Valley Archaeological Survey, Zanesville, Ohio.

Murphy, James L.

1975 An Archaeological History of the Hocking Valley. Ohio University Press, Athens.

Nolan, Kevin C., Mark F. Seeman, and James L. Theler

2007 A Quantitative Analysis of Skill and Efficiency: Hopewell Blade Production at the Turner Workshop, Hamilton County, Ohio. Midcontinental Journal of Archaeology 32:297-329.

Odell, George H.

1994 The Role of Stone Bladelets in Middle Woodland Society. American Antiquity 59:102-120.

Pacheco, Paul J., Jarrod Burks, and Dee Anne Wymer

2009a The 2006 Archaeological Investigation at Brown's Bottom \#1 (33Ro1104). Current Research in Ohio Archaeology. Electronic document, https://www. ohioarchaeology.org/resources/45-resources/research/ articles-and-abstracts-2009/285-the-2006-archaeological-investigations-at-browns-bottom-1-33r01104, accessed September 30, 2019. 
2009b The 2007-2008 Archaeological Investigations at Lady's Run (33Ro1105). Current Research in Ohio Archaeology. Electronic document, https://ohioarchaeology.org/resources/45-resources/research/articlesand-abstracts-2009/293-the-2007-2008-archaeologicalinvestigations-at-ladys-run-33r01105, accessed September 30, 2019.

2012 Preliminary Report of Results from the 2012 Archaeological Investigations at the Datum H Site, Hopewell Mound Group (33Ro26), Ross County, Ohio. Report submitted to Midwest Archeological Center and Hopewell Culture National Historical Park. Copies available from Hopewell Culture National Historical Park, Chillicothe, Ohio.

Penney, David W.

1988 Hopewell Art. PhD dissertation, Department of Art History and Archaeology, Columbia University, New York.

2004 The Archaeology of Aesthetics. In Hero, Hawk, and Open Hands: American Indian Art of the Ancient Midwest and South, pp. 43-56. Art Institute of Chicago, Chicago.

Pi-Sunyer, Oriol

1965 The Flint Industry. In The McGraw Site: A Study in Hopewellian Dynamics, edited by Olaf H. Prufer, pp. 60-89. Scientific Publication 4. Cleveland Museum of Natural History, Cleveland, Ohio.

Pluckhahn, Thomas J., Martin Menz, and Lori O'Neal

2018 Crafting Everyday Matters in the Middle and Late Woodland Periods. In Investigating the Ordinary, edited by Sarah E. Price and Philip J. Carr, pp. 112-123. University Press of Florida, Gainesville.

Plunkett, Jeffrey A.

1997 A Statistical Analysis of Chert Bifaces from the Mt. Vernon Site (12-PO-885), Posey County, Indiana. In Hopewell in Mt. Vernon: A Study of the Mt. Vernon Site, edited by the General Electric Company, pp. 219-262. General Electric, Boston.

Prufer, Olaf $\mathrm{H}$

1965 Miscellaneous Artifacts. In The McGraw Site: A Study in Hopewellian Dynamics, edited by Olaf H. Prufer, pp. 98-103. Scientific Publications No. 4. Cleveland Museum of Natural History, Cleveland, Ohio.

1968 Ohio Hopewell Ceramics: An Analysis of Extant Collection. Anthropological Papers No. 33. University of Michigan Museum of Anthropology, Ann Arbor.

Prufer, Olaf H., and Douglas H. McKenzie

1965 Ceramics. In The McGraw Site: A Study in Hopewellian Dynamics, edited by Olaf H. Prufer, pp. 16-57. Scientific Publications 4. Cleveland Museum of Natural History, Cleveland, Ohio.

Reimer, Paula J., Edouard Bard, Alex Bayliss, J. Warren Beck, Paul G. Blackwell, Christopher Bronk Ramsey, Caitlin E. Buck, Hai Cheng, R. Lawrence Edwards, Michael Friedrich, Pieter M. Grootes, Thomas P. Guilderson, Haflidi Haflidason, Irka Hajdas, Christine Hatté, Timothy J. Heaton, Dirk L. Hoffmann, Alan G. Hogg, Konrad A. Hughen, K. Felix Kaiser, Bernd Kromer, Sturt W. Manning, Mu Niu, Ron W. Reimer, David A. Richards, E. Marian Scott, John R. Southon, Richard A. Staff, Christian S. M. Turney, and Johannes van der Plicht

2013 IntCal13 and Marine13 Radiocarbon Age Calibration Curves 0-50,000 Years cal BP. Radiocarbon 55:1869-1887.
Ruby, Bret J., Christopher Carr, and Douglas K. Charles 2005 Community Organizations in the Scioto, Mann, and Havana Hopewellian Regions: A Comparative Perspective. In Gathering Hopewell: Society, Ritual, and Ritual Interaction, edited by Christopher Carr and D. Troy Case, pp. 119-176. Springer, New York.

Ruby, Bret J., and Christine M. Shriner

2005 Ceramic Vessel Composition and Styles as Evidence of the Local and Nonlocal Social Affiliations of Ritual Participants at the Mann Site, Indiana. In Gathering Hopewell: Society, Ritual, and Ritual Interaction, edited by Christopher Carr and D. Troy Case, pp. 553-572. Springer, New York.

Ruhl, Katherine, and Mark Seeman

1998 The Temporal and Social Implications of Ohio Hopewell Copper Ear Spool Design. American Antiquity 63:651-662.

Scheidegger, Edward

1968 The Crib Mound Cache Blades. Central States Archaeological Journal 15:144-147.

Seeman, Mark F.

1975 The Prehistoric Chert Quarries and Workshops of Harrison County, Indiana. Indiana Archaeological Bulletin 1:47-61.

2004 Hopewell Art in Hopewell Places. In Hero, Hawk, and Open Hands: American Indian Art of the Ancient Midwest and South, edited by Richard F. Townsend, pp. 57-72. Art Institute of Chicago, Chicago.

Seeman, Mark F., and James Branch

2006 The Mounded Landscapes of Ohio: Hopewell Patterns and Placements. In Recreating Hopewell, edited by Douglas K. Charles and Jane E. Buikstra, pp. 106121. University Press of Florida, Gainesville.

Seeman, Mark F., Kevin C. Nolan, and Mark A. Hill

2019 Copper as an Essential and Exotic Hopewell Metal. Journal of Archaeological Sciences: Reports 24:10951101.

Seeman, Mark F., and Frank Soday

1980 The Russell Brown Mounds in Ross County, Ohio. Midcontinental Journal of Archaeology 5:73-116.

Shetrone, Henry C.

1926 Explorations of the Hopewell Mound Group of Ohio. Ohio Archaeological and Historical Quarterly 35:5-227.

Shetrone, Henry C., and Emerson F. Greenman

1931 Exploration of the Seip Group of Prehistoric Earthworks. Ohio Archaeological and Historical Quarterly 40:343-509.

Smart, Tristine L., and Richard I. Ford

1983 Plant Remains. In Recent Excavations at the Edwin Harness Mound, Liberty Works, Ross County, Ohio, by N'omi Greber, pp. 54-58. MCJA Special Paper No. 5. Kent State University Press, Kent, Ohio.

Smith, Bruce D.

1992 Hopewellian Farmers of Eastern North America. In Rivers of Change: Essays on Early Agriculture in Eastern North America, pp. 201-247. Smithsonian Institution, Washington, DC.

Spence, Michael W., and Brian J. Fryer

2005 Hopewellian Silver and Silver Artifacts from Eastern North America: Their Sources, Procurement, Distribution, and Meanings. In Gathering Hopewell: Society, Ritual, and Ritual Interaction, edited by Christopher Carr and D. Troy Case, pp. 716-733. Springer, New York.

Spielmann, Katherine A.

2002 Feasting, Craft Specialization, and the Ritual Mode 
of Production in Small-Scale Societies. American Anthropologist 104:195-207.

2008 Crafting the Sacred: Ritual Places and Paraphernalia in Small-Scale Societies. In Dimensions of Ritual Economy, edited by E. Christian Wells and Patricia McAnany, pp. 37-72. Research in Economic Anthropology Vol. 27. JAI Press, Bingley, UK.

2009 Ohio Hopewell Ritual Craft Production. In Footprints: In the Footprints of Squier and Davis, edited by Mark Lynott, pp. 179-188. Special Report 5. Midwest Archeological Center, National Park Service, Lincoln, Nebraska.

2013 The Materiality of Spiritual Engagement and the End of Ohio Hopewell. World Art 3:141-162.

Squier, Ephraim G., and Edwin H. Davis

1848 Ancient Monuments of the Mississippi Valley: Comprising the Results of Extensive Original Surveys and Explorations. Contributions to Knowledge 1. Smithsonian Institution, Washington, DC.

Stoltman, James B.

2012 A Petrographic Analysis of Mound City Pottery. Appendix A in Mound City: The Archaeology of a Renown Ohio Hopewell Mound Center, by James B. Brown, pp. 375-421. Special Report 6. Midwest Archeological Center, National Park Service, Lincoln, Nebraska.

2015 Ceramic Petrography and Hopewell Interaction. University of Alabama Press, Tuscaloosa.

Stuiver, Minze, Paula J. Reimer, and Ron W. Reimer

2019 CALIB 7.1. Electronic document, http://calib.org, accessed November 29, 2019.

Walton, Clyde C. (editor)

1962 John Francis Snyder: Selected Writings. Illinois State Historical Society, Springfield.

Watanabe, John M.

2007 Ritual Economy and the Negotiation of Autarky and Interdependence in a Ritual Mode of Production. In Mesoamerican Ritual Economy: Archaeological and Ethnological Perspectives, edited by E. Christian Wells and Karla L. Davis-Salazar, pp. 301-322. University Press of Colorado, Boulder.

Wells, E. Christian

2006 Recent Trends in Theorizing Prehispanic Mesoamerican Economies. Journal of Archaeological Research 14:265-312.

Wells, E. Christian, and Karla L. Davis-Salazar (editors)

2007 Mesoamerican Ritual Economy: Archaeological and Ethnological Perspectives. University Press of Colorado, Boulder.

Wells, E. Christian, and Karla L. Davis-Salazar

2007 Mesoamerican Ritual Economy: Materialization as Ritual and Economic Process. In Mesoamerican Ritual Economy: Archaeological and Ethnological Perspectives, edited by E. Christian Wells and Karla L. Davis-Salazar, pp. 1-26. University Press of Colorado, Boulder.

Wells, E. Christian, and Patricia A. McAnany (editors)

2008 Dimensions of Ritual Economy. Research in Economic Anthropology Vol. 27. JAI Press, Bingley, UK.

Willoughby, Charles C.

1916 The Art of the Great Earthwork Builders of Ohio. In
Annual Report of the Smithsonian Institution, pp. 488 500. Smithsonian Institution, Washington, DC.

Willoughby, Charles C., and Ernest A. Hooton

1922 The Turner Group of Earthworks in Hamilton County, Ohio. Papers of the Peabody Museum of American Archaeology and Ethnology. Harvard University, Cambridge, Massachusetts.

Wimberley, Virginia S.

2004 Preserved Textiles on Hopewell Copper. In Perishable Material Culture of the Northeastern United States, edited by Penelope Drooker, pp. 69-86. New York State Museum, Albany.

Wright, Alice P.

2017 Local and "Global" Perspectives on the Middle Woodland Southeast. Journal of Archaeological Research 25:37-83.

Wright, Alice P., and Erika Loveland

2015 Ritualised Craft Production at the Hopewell Periphery: New Evidence from the Appalachian Summit. Antiquity 89:137-153.

Wymer, Dee Anne

1992 Trends and Disparities: The Woodland Paleoethnobotanical Record of the Mid-Ohio Valley. In Cultural Variability in Context: Woodland Settlement of the Mid-Ohio Valley, edited by Mark F. Seeman, pp. 65-76. Midcontinental Journal of Archaeology Special Paper No. 7. Kent State University Press, Kent, Ohio.

1996 The Ohio Hopewell Econiche: Human-Land Interaction in the Core Area. In A View from the Core: A Synthesis of Ohio Hopewell Archaeology, edited by Paul J. Pacheco, pp. 36-53. Ohio Archaeological Council, Columbus.

1997 Paleoethnobotany in the Licking River Valley, Ohio: Implications for Understanding Ohio Hopewell. In Ohio Hopewell Community Organization, edited by William S. Dancey and Paul J. Pacheco, pp. 153-172. Kent State University Press, Kent, Ohio.

Yerkes, Richard W.

1994 A Consideration of the Function of Ohio Hopewell Bladelets. Lithic Technology 19:109-127.

2009a Macro and Microscopic Analysis of "Cache Blades" and Chert Debitage from the Mound City North Forty Site (33Ro338). Report submitted to Hopewell Culture National Historical Park. Copies available from Hopewell Culture National Historical Park, Chillicothe, Ohio.

2009b Microwear Analysis of a Sample of 100 Chipped Stone Artifacts from the 1971-1977 Excavations at the Seip Earthworks. Midcontinental Journal of Archaeology 34:109-121.

Yerkes, Richard W., and G. Logan Miller

2010 Macro and Microscopic Analysis of "Cache Blades" and Chert Debitage from the Mound City North Forty Site (33Ro338). Report submitted to Hopewell Culture National Historical Park. Copies available from Hopewell Culture National Historical Park, Chillicothe, Ohio.

Submitted June 22, 2019; Revised December 2, 2019;

Accepted December 5, 2019 